\title{
Geologic Strip Map Along the Hines Creek Fault Showing Evidence for Cenozoic Displacement in the Western Mount Hayes and Northeastern Healy Quadrangles, Eastern Alaska Range, Alaska
}

By Warren J. Nokleberg, John N. Aleinikoff, Thomas K. Bundtzen, and Maiana N. Hanshaw

Pamphlet to accompany

Scientific Investigations Map 3238 


\section{Contents}

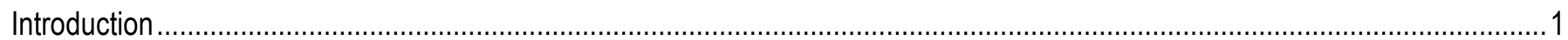

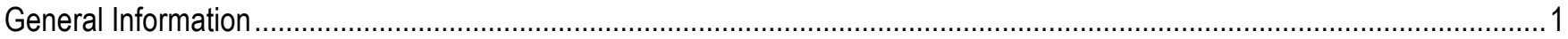

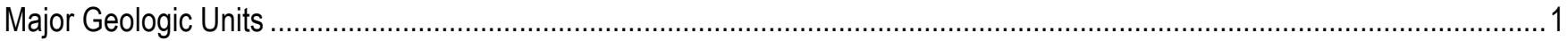

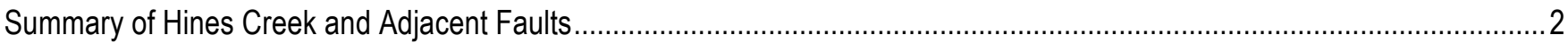

Topographic Setting of Eastern Alaska Range and Sources of Geologic Mapping ...........................................................

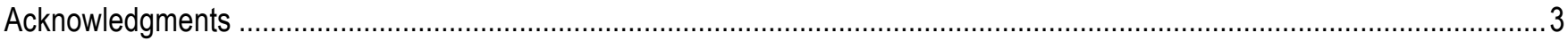

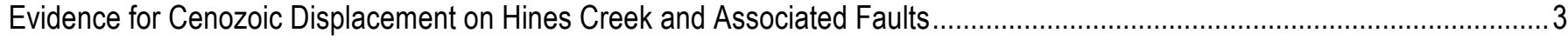

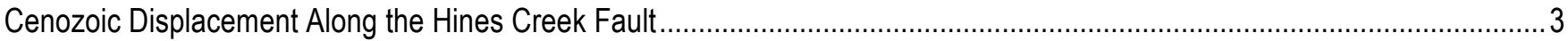

Evidence for Cenozoic Displacement Along the Trident Glacier Fault ....................................................................

Evidence for Cenozoic Displacement Along the McGinnis Glacier Fault ......................................................................

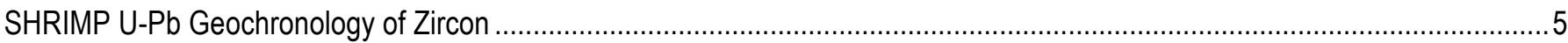

Methods

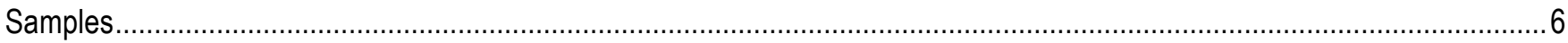

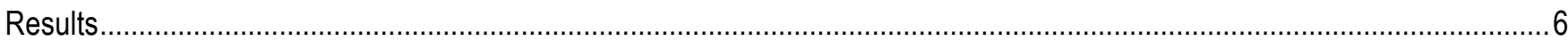

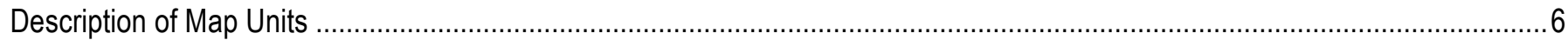

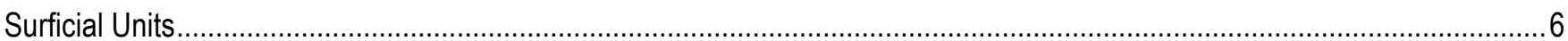

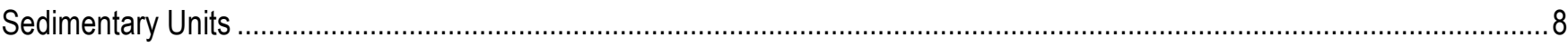

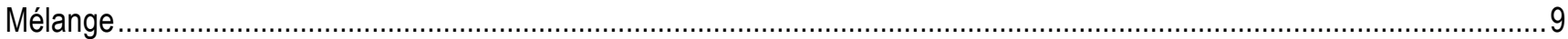

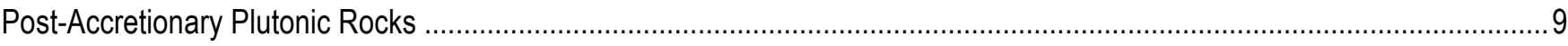

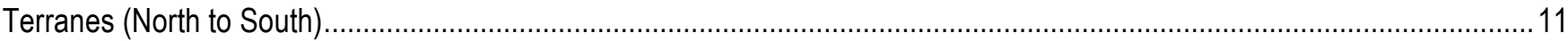

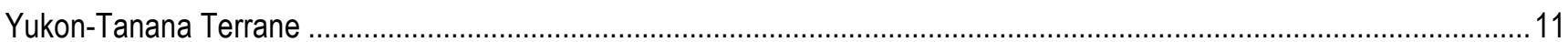

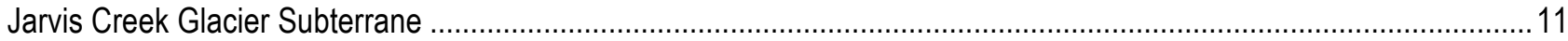

Pingston Terrane-South of Hines Creek Fault and North of Nenana Glacier and Denali Faults ..................................15

Aurora Peak Terrane-South of Nenana Glacier Fault and North of Denali Fault ............................................................. 18

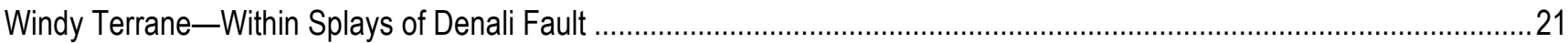

Maclaren Terrane-South of Denali Fault and North of Broxson Gulch Thrust ...........................................................2

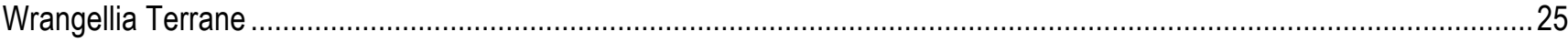

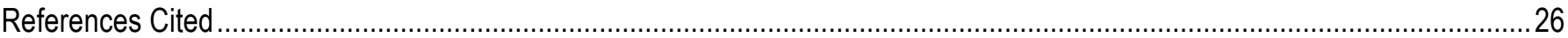

\section{Figure}

Figure 1. Representative images and SHRIMP U-Pb data from zircon from plutonic rocks.

$A, C L$ images of zircon from 10ANK001 (leucodiorite).

$B$, Tera-Wasserburg plot of SHRIMP data from 10ANK001.

$C, C L$ images of zircon from 10ANK004 CL images of zircon from 10ANK004 (porphyritic granodiorite).

$D$, Tera-Wasserburg plot of SHRIMP data from 10ANK004 (porphyritic granodiorite).

\section{Table}

Table 1. SHRIMP U-Th-Pb data for zircon from two granitic plutons near the Hines Creek Fault, Alaska. 


\section{Geologic Strip Map Along the Hines Creek Fault Showing Evidence for Cenozoic Displacement in the Western Mount Hayes and Northeastern Healy Quadrangles, Eastern Alaska Range, Alaska}

By Warren J. Nokleberg John N. Aleinikoff, Thomas K. Bundtzen, and Maiana N. Hanshaw

\section{Introduction}

\section{General Information}

This pamphlet augments the companion geologic map by providing an interpretative text describing Cenozoic faulting in the region and by providing a detailed description of map units. The companion geologic map is a strip geologic map along the Hines Creek Fault from the central and northwestern Mount Hayes quadrangle into the northeastern Healy quadrangle. The strip geologic map is provided in ArcMap GIS and Adobe PDF formats. For a listing of files and directories for the map, read the file titled 1_Hines_Creek_Fault_Map_readme.txt.

\section{Major Geologic Units}

Nine major groups of surficial units and bedrock units are present in the map area: (1) upper Pliocene, Pleistocene, and Holocene surficial units - mainly various types of alluvium, colluvium, and glacial deposits; (2) Oligocene through Pliocene sedimentary units - mainly the Nenana Gravel and an older unit of sandstone, siltstone, and lesser conglomerate; (3) an extensive suite of plutonic unitsmainly Cretaceous granodiorite and quartz monzonite; (4) Devonian and possibly older Jarvis Creek Glacier subterrane that comprises the southern part of the Yukon-Tanana terrane; (5) Silurian through Triassic metasedimentary and metavolcanic rock structural mélange (that is, a structural breccia formed of highly sheared rock fragments) of the Pingston terrane; (6) Aurora Peak terrane with Paleozoic metasedimentary rock and Cretaceous and lower Tertiary metagranitic rock; (7) sedimentary and volcanic rock structural mélange of the mainly Cretaceous Windy terrane; (8) Maclaren terrane with metamorphosed Upper Jurassic and Lower Cretaceous flysch and Cretaceous and lower Tertiary metagranitic rock; and (9) upper Paleozoic sedimentary and volcanoclastic rock, ultramafic plutonic rock, gabbro, and metagabbro of the Wrangellia terrane.

North of the Denali Fault, the bedrock geology is dominated by the Devonian and older YukonTanana terrane, a complex of multiply deformed and metamorphosed sedimentary, volcanic, and plutonic rocks (Jones and others, 1987; Aleinikoff, 1984a,b; Aleinikoff and Nokleberg, 1985a,b; Nokleberg and Aleinikoff, 1985). To the south of the fault, the bedrock geology is dominated by the Mesozoic Maclaren and Paleozoic and Mesozoic Wrangellia terranes (Jones and others, 1987; 
Nokleberg and others, 1982, 1985, 1989). A number of granitic to gabbroic plutons, chiefly of Mesozoic age, intrude the terranes both north and south of the Denali Fault. Major faults or sutures separate terranes, and many younger Cenozoic faults occur along the margins of, and within, terranes.

\section{Summary of Hines Creek and Adjacent Faults}

Geologic mapping of the Hines Creek Fault and the adjacent Trident Glacier and McGinnis Glacier Faults to the north in the eastern Alaska Range, Alaska, reveals that these faults were active during the Cenozoic. Previously, the Hines Creek Fault, which is considered to be part of the strike-slip Denali Fault system (Ridgway and others, 2002; Nokleberg and Richter, 2007), was interpreted to have been welded shut during the intrusion of the Upper Cretaceous Buchanan Creek pluton (Wahrhaftig and others, 1975; Gilbert, 1977; Sherwood and Craddock, 1979; Csejtey and others, 1992). Our geologic mapping along the west- to west-northwest-striking Hines Creek Fault in the northeastern Healy quadrangle and central to northwestern Mount Hayes quadrangle reveals that (1) the Buchanan Creek pluton is truncated by the Hines Creek Fault and (2) a tectonic collage of fault-bounded slices of various granitic plutons, metagabbro, metabasalt, and sedimentary rock of the Pingston terrane occurs south of the Hines Creek Fault.

Our geologic mapping also identified the less extensive Trident Glacier and McGinnis Glacier Faults located 1 to $5 \mathrm{~km}$ north of the Hines Creek Fault that extend for about $60 \mathrm{~km}$ in the northwest Mount Hayes quadrangle. The mapping along these faults reveals that the older bedrock of the middle to late Paleozoic Yukon-Tanana terrane is (1) juxtaposed against upper Pliocene to lower Pleistocene glacial moraines along thrust or strike-slip faults and (2) juxtaposed against Oligocene to Pliocene sedimentary rocks along thrust or strike-slip faults. To the southeast, the Trident Glacier and McGinnis Glacier Faults merge with the Hines Creek Fault that, in turn, merges with the main strand of the strikeslip Denali Fault in the area of the Delta River and Canwell Glacier.

Field relations for the Hines Creek and adjacent faults to the north indicate the following: (1) the faults have been active throughout most of the Cenozoic, (2) the faults exhibit young (Pleistocene) movement; (3) the three faults have potential for future movement; and (4) the faults are major parts of the Alaska Range suture zone. In addition, a recent geophysical transect study, east of the Parks Highway in the central Healy quadrangle, also revealed that the Moho is offset across the Hines Creek Fault and that the fault may be a major crustal boundary in eastern Alaska (Veenstra and others, 2006). For additional information about the entire Mount Hayes quadrangle, including previous studies and more detailed descriptions of map units, refer to Nokleberg and others (1992a,b).

\section{Topographic Setting of Eastern Alaska Range and Sources of Geologic Mapping}

The area underlain by the strip map, the central and northwestern Mount Hayes and northeastern Healy quadrangles, form a major part of the eastern Alaska Range. The range is a great glacially sculptured arcuate mountain range extending approximately $1,000 \mathrm{~km}$ from near the Canadian border in the east to the Aleutian Range to the west and southwest. The eastern Alaska Range features rugged peaks ranging to over $13,800 \mathrm{ft}$ in elevation and spectacular alpine glaciers as long as $66 \mathrm{~km}$. The range is bisected by the Denali Fault, which is a major geologic and geographic boundary between the Yukon River Basin in interior Alaska to the north and the Copper River Basin of southern Alaska to the south.

From the 1950s to the 1990s, geologic maps of parts of the central Mount Hayes quadrangle and northeastern Healy quadrangles, the area underlying this strip map, were published by Bond (1976), Gilbert (1977), Sherwood and Craddock (1979), Brewer (1982), Csejtey and others (1992), and Nokleberg and others (1992b). Surficial geologic maps of the central part of the Mount Hayes quadrangle, mostly along the Delta River and adjacent Richardson Highway, were published by Holmes and Benninghoff (1957), the U.S. Army Corps of Engineers (1960), Weber (1971), and Carter and 
Galloway (1978). The geologic map described herein is based partly on these published geologic maps but to a much greater degree on the 1:63,360-scale geologic mapping completed for the geologic map of the Mount Hayes quadrangle that was published at a scale of 1:250,000 (Nokleberg and others, 1992b) and on new geologic mapping by the authors for the northeast Healy quadrangle.

This geologic map is based on mapping of 1:63,360-scale quadrangles from the central and northwestern Mount Hayes to the northeastern Healy quadrangles, including parts of the Mount Hayes B4, B5, C4, C5, C6 and D6 quadrangles and the Healy C6 and D6 quadrangles. The geologic mapping was supported by the Alaskan Mineral Resource Assessment Program (AMRAP) of the U.S. Geological Survey during the summers of 1978-1982, 1985, and 1986 as part of the Trans-Alaskan Transect Program (TACT) (Fuis and others, 2008).

\section{Acknowledgments}

We are greatly indebted to the hard work and excellent science published by present and past geologists in the Mount Hayes quadrangle and adjacent areas as described above. Our work is, in part, based on their fine efforts and accomplishments. We are grateful to H.C. Berg, Donald Grybeck, E.M. MacKevett, Jr., A.T. Ovenshine, T.P. Miller, and G.R. Winkler, who greatly encouraged and supported the geologic mapping. We thank D.L. Jones and N.J. Silberling for their stimulating geological discussions of bedrock geology and tectonics. We thank D.L. Campbell, P.L. Herzon, the late Carl Huie, I.M. Lange, J.S. Lull, R.T. Miyaoka, George Plafker, S.R. Silva, and R.E. Zehner for assisting in part of the bedrock geologic mapping, and L.D.Carter, T.D. Hamilton, and Warren Yeend for assisting in mapping of surficial deposits and older Quaternary and Holocene faults. We also thank the late G.C. Bond and J.H. Stout for contributing unpublished geologic mapping of parts of the quadrangle. We thank C.L. Burhmaster, R.C. Roback, and C.E. Schwab for extensive petrologic studies of bedrock in the quadrangle. We also thank helicopter pilots Michael Arline, Richard Rossiter, and Barry Roberts for their superb flying in an extremely difficult and remote area. We thank N.B. Shew for assisting in providing digital topographic base maps. We thank P.J. Haeussler and T.E. Moore for their constructive scientific reviews.

\section{Evidence for Cenozoic Displacement on Hines Creek and Associated Faults}

This geologic map reveals that the Hines Creek Fault and associated faults to the north have been active in the Cenozoic. The data supporting this revelation are revealed by examination of the juxtaposition of various units along the faults.

\section{Cenozoic Displacement Along the Hines Creek Fault}

The Hines Creek Fault extends from an area of acute convergence with the Denali Fault in the center of the Mount Hayes B-4 quadrangle to the western edge of the strip map in the Healy D-6 quadrangle, a distance of about $96.5 \mathrm{~km}$. Farther west, the fault continues across the northern part of the Healy quadrangle and westward into the central part of the Mount McKinley quadrangle, where it merges with the Denali Fault. The total length of the Hines Creek Fault is about $275 \mathrm{~km}$.

In the area of the strip map, the fault is the locus of thrusting of Silurian to Triassic Pingston terrane, located to the south and southwest, over the Jarvis Creek Glacier subterrane, located to the north and northeast.

The following observations are the major data indicating Cenozoic displacement. The letters $(A, B, C, D)$ correspond with the Cenozoic faulting observation sites labeled on the map.

A. Along the east-southeast part of the Hines Creek Fault in the Mount Hayes B-4 quadrangle, where the metasedimentary rocks of the Jarvis Creek Glacier subterrane are juxtaposed against the high-grade metasedimentary rocks of the Aurora Peak terrane, the glacial valley 
of the Black Rapids Glacier displays a minor dextral deflection along the fault. Also in this area, both bedrock units contain abundant brittle shears (microfaults).

B. To the northwest in the Mount Hayes C-6 quadrangle, the Hayes Glacier valley displays dextral deflection across the fault.

C. Farther west-northwest in the Healy C-6 quadrangle, the Gillam Glacier valley displays dextral deflection across the fault.

D. To the west-northwest of the Gillam Glacier in the Healy C-6 and D-6 quadrangles, a collage of fault-bounded wedges of various granitic plutons trend parallel to the fault. The wedges of granitic plutons possess unique compositions, are internally homogenous, do not have finegrained margins and do not contain stoped inclusions of wall rock. The wedges of the granitic plutons are (1) leucodiorite and granodiorite of Buchanan Creek (unit Kbc); (2) the herein informally named porphyritic granodiorite of Vertical Angle Bench Mark (VABM) Marganne (unit Km) with K-Ar biotite and hornblende ages ranging from 101.8 to 92.6 Ma (Sherwood and Craddock, 1979; Csejtey and others, 1992); (3) an unnamed granodiorite (unit Kgd); and (4) an unnamed gabbro (unit mgb) that may be part of the Yukon-Tanana terrane. The wedges of granitic plutons are juxtaposed along the fault or against metasedimentary rock of the Jarvis Creek Glacier subterrane.

The evidence for fault juxtaposition includes (1) planar surfaces with abundant brittle shears (microfaults) along the faults; (2) no diking or stoping of one granite pluton by the other, indicating that the contacts are not intrusive; (3) no contact metamorphism of adjacent rock along contacts; and (4) occurrence of a structural mélange (unit $\mathrm{m}$ ) of highly deformed (with abundant brittle shears (microfaults)) marble, chert, metavolcanic, and metasedimentary rock, diorite, and porphyritic granodiorite rock (unit $\mathrm{m}$ ) along the Hines Creek Fault.

The occurrence of four wedges of distinct, fault-bounded granite plutons along the Hines Creek Fault poses some major and unsolved questions. From which plutons along strike did each of the four wedges originate? What are the timings of displacements?

\section{Evidence for Cenozoic Displacement Along the Trident Glacier Fault}

The Trident Glacier Fault extends from an area of acute convergence with the Hines Creek Fault in the toe of the Nenana Glacier in the Mount Hayes C-5 quadrangle along a northwest strike to the northern edge of the Mount Hayes C-6 quadrangle for a distance of about $39 \mathrm{~km}$. The fault is defined as the locus of thrusting of bedrock units to the southwest over surficial units to the northeast and the locus of dextral slip.

The following observations are the major data indicating Cenozoic displacement. The letters $(E, F, G, H)$ correspond with the Cenozoic faulting observation sites labeled on the map.

E. Near the intersection with the Hines Creek Fault, the glacial valley of the northern branch of the Nenana Glacier displays dextral deflection.

F. Farther northwest, on the ridge to the northwest of the Nenana Glacier, a unit of colluvium (unit Qc) and the metavolcanic rock of the Jarvis Creek Glacier subterrane (unit jcv) to the southwest are thrust over the upper Pliocene or lower Pleistocene (Illinoian or Wisconsin stages) moraine (unit Qom) to the northeast. Local brittle shears (microfaults) occur in the bedrock units adjacent to this part of the fault.

G. Farther northwest on the ridge to the northwest of the Trident Glacier along the fault for about $16 \mathrm{~km}$, the Jarvis Creek Glacier subterrane is thrust northeastward over a high, wide, and long upper Pliocene or lower Pleistocene (Illinoian or Wisconsin stages) moraine (unit Qom) and over the unit of Oligocene and Pliocene sandstone and siltstone (unit Ts). 
H. Farther northwest, in the southern Mount Hayes D-6 quadrangle, the metavolcanic and metasedimentary rocks of the Jarvis Creek Glacier subterrane (unit jcv) is thrust northeastward over the unit of Oligocene and Pliocene sandstone and siltstone (unit Ts).

\section{Evidence for Cenozoic Displacement Along the McGinnis Glacier Fault}

The McGinnis Glacier Fault extends from an area of acute convergence with the Hines Creek Fault on the ridge northwest of the terminus of the Black Rapids Glacier in the Mount Hayes C-4 quadrangle to the northern edge of the map along a northwest strike for a distance of about $22.5 \mathrm{~km}$. The fault is the locus of both northeastward thrusting and dextral strike-slip displacement.

The following observations are the major data indicating Cenozoic displacement. The letters $(\mathrm{I}, \mathrm{J}, \mathrm{K})$ correspond with the Cenozoic faulting observation sites labeled on the map.

I. Near the intersection with the Hines Creek Fault, brittle shears (microfaults) that crosscut a penetrative schistosity occur within the bedrock of the Jarvis Creek Glacier subterrane and schistosity is opposed along the fault.

J. Farther northwest on the ridge north of the toe of the Nenana Glacier, the unit of Tertiary sedimentary rock (unit Ts) is thrust northeastward over the metavolcanic unit of the Jarvis Creek Glacier subterrane (unit jcv) along a fault contact containing abundant brittle shears.

K. Farther northwest, north of the toe of the McGinnis Glacier, fluviolacustrine deposits (unit Qfl) contain abundant shears (microfaults) along the fault. About $6.4 \mathrm{~km}$ northwest, brittle shears (microfaults) occur within the bedrock of the Jarvis Creek Glacier subterrane (unit jcs) and within an adjacent alluvial fan (unit Qaf), an observation also describe by Woodward-Lundgren and Associates (1974). Based on subtle topographic ridges that are interpreted as Holocene mole track pressure ridges, the fault extends northwest to the edge of the strip map.

\section{SHRIMP U-Pb Geochronology of Zircon}

Controversy has existed about whether the Buchanan Creek pluton intruded across the Hines Creek Fault in the Late Cretaceous and thereby welded the fault. Supporting the intrusion of the Buchanan Creek pluton across the fault is one set of data that shows similar K-Ar biotite and hornblende ages for samples of granite on opposite sides of the fault. However, as described below, this map reveals a tectonic collage of various granite plutons that are structurally juxtaposed along the various strands of the Hines Creek Fault. In order to resolve the isotopic age dilemma of similar ages for these plutons, new samples of the highly different granite plutons on opposite sides of the Hines Creek Fault were collected for SHRIMP U-Pb zircon isotopic analysis. As described below, this analysis reveals significantly different ages and zircon morphologies for the leucodiorite and granodiorite of Buchanan Creek as compared to the porphyritic granodiorite of VABM Marganne.

\section{Methods}

U-Pb geochronology of zircon was performed using the U.S. Geological Survey/Stanford University sensitive high resolution ion microprobe-reverse geometry (SHRIMP-RG). About $2 \mathrm{~kg}$ of rock were collected from outcrops for each dated sample. Zircon was extracted using standard mineral separation techniques, including crushing, pulverizing, Wilfley table, magnetic separator, and heavy liquids. Individual grains were hand picked, mounted in epoxy, ground to half-thickness to expose internal zones, and polished sequentially using $6 \mu \mathrm{m}$ and $1 \mu \mathrm{m}$ diamond suspension. All grains were digitally imaged in transmitted and reflected light using a petrographic microscope and in cathodoluminescence (CL) using a scanning electron microscope. 
Following the methods of Williams (1998), SHRIMP analysis consisted of excavating a pit about 25-35 $\mu \mathrm{m}$ in diameter to a depth of $0.5-1 \mu \mathrm{m}$, using a primary oxygen beam at a current of about 5-6 nA. The magnet cycled through the mass stations five times per analysis. Raw data were reduced using Squid 2 (Ludwig, 2009) and plotted using Isoplot 3 (Ludwig, 2003). Instrument fractionation for

${ }^{206} \mathrm{~Pb} /{ }^{238} \mathrm{U}$ ages was corrected using zircon standard R33 (419 $\pm 1 \mathrm{Ma}$; Black and others, 2004). Uranium concentrations are believed to be accurate to $\pm 20 \%$. U-Pb data are plotted on Tera-Wasserburg concordia plots to visually identify coherent age groups. Weighted averages of selected individual ${ }^{206} \mathrm{~Pb} /{ }^{238} \mathrm{U}$ ages were calculated to obtain an age for each sample.

\section{Samples}

As shown by representative CL images, zircon from the two dated plutonic rocks have distinctly different morphologies. Zircon from sample 10ANK001 (leucodiorite of Buchanan Creek that occurs north of the Hines Creek Fault) is colorless and slightly deformed and has pitted crystal faces and numerous small inclusions. All grains contain fine, concentric CL zoning (fig. $1 \mathrm{~A}$ ). Zircon from sample 10ANK004 (porphyritic granodiorite of VABM Marganne that occurs south of the Hines Creek Fault) is colorless, and relatively pristine, and has mirror-like crystal faces and a few large inclusions. All grains contain fine to medium CL zoning (fig. 1C). The outermost parts of many grains are composed of dark, unzoned material that resembles a homogeneous igneous component. Alternatively, despite the undeformed character of the grains, we considered the possibility that the dark rims might be metamorphic in origin. These outermost areas were targeted for SHRIMP analysis to determine their origin.

\section{Results}

Sixteen (of 17) analyses of cores of zircon from 10ANK001 (table 1) yield a weighted average age of $94.7 \pm 1.4 \mathrm{Ma}$ (fig. $1 B$ ). This age is interpreted as the time of emplacement of the leucodiorite of Buchanan Creek. One slightly younger analysis was excluded from the age calculation. Five dark (in $\mathrm{CL}$ ), unzoned, homogeneous tips have ages that are similar to the core ages, indicating that these zones formed as part of the magmatic process; they do not represent a later metamorphic event.

Fourteen (of 18) analyses of cores of zircon from 10ANK004 (table 1) yield a weighted average age of $98.0 \pm 1.4 \mathrm{Ma}($ fig. $1 D$ ). This age is interpreted as the time of emplacement of the porphyritic granodiorite of VABM Marganne. Four slightly younger ages were excluded from the age calculation.

Although both samples listed in table 1 have early Late Cretaceous ages, the different SHRIMP ages support the interpretation, based on compositional differences, that these are two distinctly different plutons. Furthermore, zircon from the younger rock (leucodiorite of Buchanan Creek; 94.7 $\pm 1.4 \mathrm{Ma}$ ) is slightly damaged, suggesting a complicated post-emplacement history, whereas zircon from the older rock (porphyritic granodiorite of VABM Marganne; $98.0 \pm 1.4 \mathrm{Ma}$ ) is pristine. This morphologic variability is additional evidence for the interpretation that these rocks evolved separately and were tectonically juxtaposed well after crystallization.

\section{DESCRIPTION OF MAP UNITS}

\section{SURFICIAL UNITS}

Qi Icefield, glacier, and lesser unconsolidated deposits of Alaska glaciation (Holocene) - Chiefly icefield, small glacier, and lesser unconsolidated sand and gravel on flood-plains, fans, and cones. Only large, well-defined cones differentiated from colluvium. Oldest deposits may be outwash from a late 
advance of the Wisconsin stage glaciation. Includes unconsolidated rocks in stream beds and river beds

Qa Alluvial deposits (Holocene) — Chiefly unconsolidated sand and gravel in floodplains and minor, gentle-gradient fans. Only large, well-defined fans differentiated from colluvium. Oldest deposits may be outwash from a late advance of the Wisconsin stage glaciation

Qc Colluvial deposits and minor lateral moraine (Holocene) - Chiefly talus and other slope debris deposits. Also includes alluvium of minor streams and, locally, glacial, rock glacier, and mass-wasting deposits. In areas of gentle slopes, consists chiefly of mixed colluvium and alluvium with local bedrock rubble but may include older glacial drift deposits. Locally grades into deposits of Alaskan, Wisconsin, and older glaciations. Chiefly rubble, gravel, sand, silt, and clay

Qaf Alluvial fan (Holocene) - Chiefly fans and cones. Only large, well-defined cones differentiated from colluvium. Oldest deposits may be outwash from a late advance of the Wisconsin stage glaciation. Chiefly unconsolidated sand and gravel

Qam Alaskan neoglaciation lateral and terminal moraine and glacial debris from Alaskan glaciation (Holocene) - Chiefly rubble and diamicton left after recession of existing glaciers

Qrg Rock glacier (Holocene) - Chiefly unconsolidated boulder, gravel, and sand that occur downslope from a glacier cirque. Contains ice core

Qfl Fluviolacustrine deposits (Holocene) - Chiefly sand, silt, and clay in lakes, ponds, and low-gradient streams

Qoa Older, uplifted alluvium and minor lateral moraine (Holocene and Pleistocene) - Chiefly unconsolidated sand and gravel in uplifted terraces along Denali Fault

Qwm Wisconsin stage glaciation lateral moraine (Holocene and Pleistocene) — Chiefly poorly sorted and unstratified till of unconsolidated sand and gravel. Mainly consists of rubble and diamicton of local sand and gravel. May locally include deposits of neoglaciation (Qam). At higher elevations, deposits grade vertically with and are covered by colluvium (Qc)

Qwf Wisconsin stage glaciation glaciofluvial deposits (Holocene and Pleistocene)Chiefly moderately well stratified layers and lenses of well-rounded gravel with matrix of silt and sand. Contains poorly to moderately well sorted gravel and sand with local lenses of well-sorted sand. Includes minor lateral and ground moraines and some deposits of Alaskan neoglaciation (Qam). May include postglacial alluvium and pond deposits. Generally occurs downslope from end moraines of Wisconsin stage glaciation (Qwm)

Qom Illinoian stage or early Wisconsin stage lateral moraine (lower Pleistocene or upper Pliocene) - Chiefly poorly sorted and unstratified till of unconsolidated sand and gravel. Occurs in a large lateral moraine about $16 \mathrm{~km}$ wide (in an east-west direction) and $30 \mathrm{~km}$ long (in a north-south direction) in the Mount Hayes C-5 and D-5 quadrangles. Occurs between paired Wisconsin stage glaciation lateral moraines (Qwm) in the Mount Hayes C-5 and C-6 quadrangles 
Qog Drift of older glaciations (lower Pleistocene or upper Pliocene) - Chiefly small areas on canyon walls consisting of poorly sorted and unstratified till of unconsolidated sand and gravel. Unit occurs above and adjacent to Wisconsin stage glacial moraines along west side of Delta River canyon

\section{SEDIMENTARY UNITS}

Scattered exposures of Tertiary continental sedimentary rocks occur north of the Denali Fault and consist of, from youngest to oldest, the Nenana Gravel and a sandstone unit. The Nenana Gravel occurs mainly in the northwestern corner of the Mount Hayes quadrangle. The sandstone unit occurs mainly in fault-bounded prisms along the northern edge of the Alaska Range along the Hines Creek and associated faults.

$\mathrm{Tn}$

Ts
Nenana Gravel (lower Pliocene to upper Miocene) - Consists chiefly of poorly cemented conglomerate but includes some sandstone and siltstone. Clast composition within the Mount Hayes D-6 quadrangle (in decreasing order of abundance) is schist, quartzite, granitic rocks, gabbro, and metagabbro. At one locality in the Mount Hayes C-3 quadrangle, clasts consist of approximately $80 \%$ schist, $10 \%$ quartzite, and $10 \%$ felsic volcanic rocks, mafic volcanic rocks, and diabase. Bedding strikes northeast and dips gently south in the Mount Hayes D-6 quadrangle. Eroded at top. Maximum exposed stratigraphic thickness of a few hundred meters

Unit is mainly exposed along northern Mount Hayes D-6 quadrangle boundary and northeastern C-4 quadrangle. Unconformably overlies finegrained metasedimentary rocks (jcs) of Jarvis Creek Glacier subterrane; locally in fault contact with Jarvis Creek Glacier terrane (unit jcs). Unconformably overlain by Pleistocene glacial deposits, and locally unconformably overlies the sandstone unit of Oligocene to Pliocene age (unit Ts). Inferred to be of upper Tertiary (Pliocene) age. Lithologically similar to rocks assigned to Nenana Gravel. Gravel unit, which occurs to west in the Healy quadrangle, is assigned a Miocene(?) and Pliocene age by Csejtey and others (1992)

Sandstone, siltstone, and lesser conglomerate (Pliocene to Oligocene) - Chiefly brown graywacke sandstone but includes some interbedded conglomerate and dark argillite. Generally fault bounded. Maximum exposed stratigraphic thickness of a few hundred meters

Unit consists mainly of fine- to medium-grained, poorly sorted, angular quartz-rich sandstone that grades into graywacke. Composition varies from quartz grains in a clay-rich matrix to quartz, plagioclase, K-feldspar, pyroxene, hornblende, and biotite in a clay-rich matrix. Conglomerate pebbles locally composed of granitic rocks and schist; locally imbricated. Argillite composed of tiny quartz grains and opaque minerals in a yellow-brown, clayrich matrix

Unit occurs in scattered exposures as much as $3.5 \mathrm{~km}$ across in the Mount Hayes C-5, C-6, D-5, and D-6 quadrangles. Strikes northeast and dips moderately west in the C-5 quadrangle. Overlies and locally faulted against rocks of the Jarvis Creek Glacier subterrane. Sparse plant fossils indicate Oligocene, Miocene, and Pliocene age (Nokleberg and others, 1992a, table 1, localities $1,2,3,4,6$ ) 


\section{MÉLANGE}

$\mathrm{m}$

Structural mélange along Hines Creek Fault (Holocene to Paleocene)—Consists

of structurally imbricated lenses of low-grade metasedimentary rock, metavolcanic schist, and granite, with local abundant brittle shears (microfaults) that occur in a narrow zone adjacent to the Hines Creek Fault in the Mount Hayes D-6 and Healy D-1 quadrangles. Zone is as wide as $300 \mathrm{~m}$ and extends for about $7 \mathrm{~km}$. Mélange mainly occurs along northern edge of porphyritic granodiorite of VABM Marganne $(\mathrm{Km})$. Units adjacent to the structural mélange also contain abundant brittle shears (microfaults)

\section{POST-ACCRETIONARY PLUTONIC ROCKS}

Extensive areas of granitic plutonic rocks occur in terranes north of the Denali Fault as small dikes, stocks, and a few large plutons. Some occurrences are too small to depict on the geologic map. The larger plutons are at Buchanan Creek and Molybdenum Ridge in the northwest Mount Hayes quadrangle. The granitic rocks are generally equigranular to porphyritic and medium grained and usually contain both hornblende and biotite.

Kbc Leucodiorite and granodiorite of Buchanan Creek (lower Tertiary to Upper Cretaceous) - Chiefly fine- to medium-grained biotite-hornblende leucodiorite with lesser granodiorite. Fine- to medium-grained, hypidiomorphic granular texture. Major igneous minerals are quartz, K-feldspar, plagioclase, hornblende, and biotite. Locally altered, fractured, and coarse grained, and contains a local weak schistosity. Plagioclase is partially recrystallized to sericite; hornblende and biotite to chlorite. Intrudes Jarvis Creek Glacier subterrane (unit jcv). Southern margin locally terminated along the Hines Creek Fault. As illustrated on the thin section microphotograph on the map, the leucodiorite of Buchanan Creek is fine to medium grained with a low color index, contains abundant plagioclase and little to no K-feldspar, and is quartz poor

Unit occurs in an area approximately $15 \mathrm{~km}$ across in the southern Healy D-1 quadrangle and extends eastward into the Mount Hayes D-6 quadrangles. Intrudes and contains inclusions of fine-grained, schistose metavolcanic rocks and metasedimentary rocks (jcv) of the Jarvis Creek Glacier subterrane. Locally intruded by andesite and granite dikes as wide as $1 \mathrm{~m}$

A Late Cretaceous or early Tertiary age is inferred from intrusion into rocks of the Jarvis Creek Glacier subterrane, subsequent to the main phase of the Lower to middle Cretaceous metamorphism. Slight schistosity and sericite and chlorite alteration of the unit most likely occurred during the waning stages of metamorphism

Km Porphyritic granodiorite of VABM Marganne (lower Tertiary to Upper Cretaceous) - Chiefly medium- to coarse-grained, biotite-hornblende porphyritic granodiorite with pink K-feldspar phenocrysts to $2 \mathrm{~cm}$ diameter. Seven K-Ar hornblende ages range from 101.8 to 93.2 Ma (Sherwood and Craddock, 1979; Csejtey and others, 1992). Unit occurs in southern Healy D-1 and northern Healy $\mathrm{C}-1$ quadrangles in fault-bounded wedge south of metavolcanic rocks of Jarvis Creek Glacier subterrane (unit jcv) and north of unnamed granodiorite (unit Kgd). Local brittle shears (microfaults) along 
margins. Wedge is about $20 \mathrm{~km}$ long and as wide as $3.2 \mathrm{~km}$. As illustrated on the thin-section microphotograph on the map, the porphyritic granodiorite of VABM Marganne is coarse to medium grained with a moderate color index, contains pink $\mathrm{K}$-feldspar phenocrysts ranging to $2 \mathrm{~cm}$ diameter, and is quartz rich

Kmo Granodiorite of Molybdenum Ridge (lower Tertiary to Upper Cretaceous) -

Chiefly biotite-hornblende granodiorite with lesser granite and quartz diorite. Contains local inclusions of fine-grained metasedimentary rocks (jcs) of Jarvis Creek Glacier subterrane. Unit is medium grained with ahypidiomorphic granular texture and local phenocrysts of plagioclase to $4 \mathrm{~mm}$. Major minerals are plagioclase, K-feldspar, quartz, hornblende, and biotite. Hornblende is locally replaced by biotite. Displays a weak local schistosity near contact with unit jcs. Locally fractured and granulated. Contains local hydrothermal alteration with hornblende and biotite partially replaced by chlorite and plagioclase by white mica. Unit exposed in an irregular body approximately $9 \mathrm{~km}$ across. Intrudes and locally faulted against fine-grained metasedimentary rocks (jcs) of the Jarvis Creek Glacier subterrane; intruded by granite, rhyolite, dacite, and andesite dikes approximately $1 \mathrm{~m}$ wide. An Upper Cretaceous age of intrusion indicated from $\mathrm{K}-\mathrm{Ar}$ biotite and hornblende dates, and $\mathrm{U}-\mathrm{Pb}$ zircon ages range from 84 to $93 \mathrm{Ma}$ (Nokleberg and others, 1992a, table 2, locality 13). Distinguished from other nearby granitic plutons by above features

Kgd Unnamed granodiorite (Upper Cretaceous) - Chiefly biotite-hornblende granodiorite. Medium grained. Occurs in southern Healy D-1 and northern Healy C-1 quadrangles in a fault-bounded wedge south of porphyritic granodiorite of VABM Marganne and north of metavolcanic and lesser metasedimentary rocks of Pingston terrane. Local brittle shears (microfaults) along edges. Fault-bounded wedge is about $18 \mathrm{~km}$ long and $1.5 \mathrm{~km}$ wide. Unit differs from leucodiorite of Buchanan Creek in having a smaller grain size and higher color index

Kqm Unnamed granite (Upper Cretaceous) - Chiefly an elongate fault-bounded wedge of granite exposed in a thin, fault-bounded wedge approximately $1 \mathrm{~km}$ wide and $12 \mathrm{~km}$ long in fault contact with Aurora Peak terrane to the northeast and Windy terrane to the southwest in the northwest Mount Hayes B-4 quadrangle. Fine to coarse grained. hypidiomorphic granular and locally porphyritic with phenocrysts of plagioclase to $5 \mathrm{~mm}$. Major minerals are quartz, plagioclase, K-feldspar, biotite, and hornblende. Unit displays a local weak to intense hydrothermal alteration and is locally schistose. Plagioclase is partially recrystallized to sericite; biotite to chlorite plus epidote-clinozoisite. Contains local quartz and calcite veins

Unit occurs in an area between the Windy and Aurora Peak terranes in Mount Hayes B-4 quadrangle. Unit exhibits K-Ar biotite and hornblende ages of 85.2, 85.9, 89.6, and 94.7 Ma (Nokleberg and others, 1992a, table 2, localities 39, 40, 41). These K-Ar values may be minimum ages for the pluton because of low-grade hydrothermal alteration and (or) low-grade static metamorphism 
Unit also includes a small pluton intruding metasedimentary rock of pingston terrane (unit pis) in central Mount Hayes C-6 quadrangle. Also includes locally numerous dikes and sills rarely more than $1 \mathrm{~m}$ across

mgb Metamorphosed gabbro and diabase (Upper Triassic) - Chiefly hornblende metagabbro and metadiabase and minor amphibolite. Unit is generally fine to medium grained with hypautomorphic granular to diabasic texture; locally porphyritic texture. Major minerals are plagioclase, hornblende, local biotite, and minor clinopyroxene, orthopyroxene, quartz, sphene, and opaque minerals. Hornblende and biotite are partially replaced by chlorite and epidote, and plagioclase by sericite, calcite, and epidote. Unit is variably metamorphosed to greenschist facies and locally schistose. Occurs in (1) southeastern Healy D-1 quadrangle (western part of map) in a narrow fault-bounded wedge south of leucodiorite of Buchanan Creek (unit Kbc) and north of unnamed granodiorite (unit $\mathrm{Kgd}$ ) in a wedge about $5 \mathrm{~km}$ long and 1 km wide and (2) northern Mount Hayes B-4 and southern Mount Hayes C-4 quadrangles (eastern part of map) as scattered dikes and small bodies intruding Jarvis Creek Glacier subterrane. An Upper Triassic crystallization age of $225.8 \pm 0.7 \mathrm{Ma}$ (by U-Pb zircon analysis) was obtained for a suite of gabbro sills intruding the metasedimentary and metavolcanic rocks of the Jarvis Creek Glacier subterrane in the Bonnifield mining district in the northern Healy D-1 quadrangle (Dashevsky and others, 2003; Dusel-Bacon and others, 2006)

\section{TERRANES (NORTH TO SOUTH)}

\section{YUKON-TANANA TERRANE}

Adjacent to and north of the Hines Creek Fault, the southern part of the Yukon-Tanana terrane consists of unnamed metagabbro and metadiabase and the Jarvis Creek Glacier subterrane (Nokleberg and others, 1992b) that contains two major units: (1) metavolcanic rock with lesser metasedimentary rock (Upper Devonian) and (2) metasedimentary schist (Devonian and older). The Yukon-Tanana terrane is interpreted as a highly metamorphosed and deformed Devonian submarine continental-margin igneous arc (Aleinikoff, 1984a,b; Dusel-Bacon and Aleinikoff, 1985; Nokleberg and Aleinikoff, 1985; Aleinikoff and others, 1986, 1987; Nokleberg and others, 1989, 1992b; Nokleberg and Richter, 2007).

\section{Jarvis Creek Glacier Subterrane}

The Jarvis Creek Glacier subterrane (Aleinikoff and Nokleberg, 1985a; Nokleberg and Aleinikoff, 1985) occurs across the northern part of the Mount Hayes quadrangle and northwestern part of the Healy quadrangle. The subterrane consists of fine-grained, polydeformed schists derived from Devonian and Mississippian sedimentary rocks and Devonian metavolcanic and metagranitic rocks.

This subterrane is subdivided into two units: (1) a metasedimentary rock unit (jcs) composed chiefly of fine-grained metasedimentary rocks and very minor metavolcanic rocks and (2) a metavolcanic rocks unit (jcv) composed chiefly of fine-grained metavolcanic rocks and moderate amounts of fine-grained metasedimentary rocks.

The metasedimentary and metavolcanic rocks are almost totally recrystallized and are composed of varying proportions of pelitic schist, quartzite, calc-schist, quartz-feldspar schist, and marble. Protoliths are shale, quartz sandstone, marl, sandstone, volcanic graywacke, and limestone. The metavolcanic rocks consist of varying proportions of abundant metaandesite and metamorphosed quartz keratophyre, less abundant metadacite and metabasalt, and very minor metarhyodacite. 
The metasedimentary and metavolcanic rock units were ductily deformed and regionally metamorphosed at greenschist facies into mylonitic schist or local phyllonite (Nokleberg and others, 1986).

jcs Fine-grained metasedimentary rocks (Devonian and older) - Chiefly fine-grained, mylonitic metasedimentary rocks. Unit comprised of approximately $65 \%$ quartz-mica schist; $15 \%$ quartzite; and 5\% each of chlorite-white mica schist, quartz-biotite schist, calc-schist, and marble. Protoliths of the unit are mainly pelite, quartz sandstone, graywacke, marl, and limestone. Intense deformation and recrystallization has obliterated most relict minerals and textures. The unit has an estimated structural thickness of a few thousand meters

Quartz-mica schists are fine grained and consist of (in descending order of abundance) quartz-white mica schist; quartz-white mica-chlorite schist; quartz-white mica calcite schist; quartz-white mica calcite-chlorite schist; quartz-white mica-garnet-chlorite schist; and garnet-white mica quartz schist. Common minor minerals are epidote, garnet, K-feldspar, graphite, sphene, and rarely tourmaline and cordierite. Porphyroblasts are chiefly quartz, plagioclase, garnet, and K-feldspar and average $1 \mathrm{~mm}$ across, rarely exceeding $3 \mathrm{~mm}$ across. Rare relict clastic quartz and plagioclase grains are present. Compositional layering is generally parallel to schistosity, defined principally by alternating bands and lenses of schistose micas and granular quartz and feldspar. Variably distorted, fractured, and granulated quartz and plagioclase form augen or augen-shaped aggregates that accompany bent mica and local helicitic garnet. Unit contains local blastomylonite. Plagioclase and andalusite are locally replaced by white mica, and biotite by chlorite

Quartzite grain size averages approximately $1 \mathrm{~mm}$ with scattered porphyroclasts to $2 \mathrm{~mm}$. No relict sedimentary textures are present. Common major minerals are quartz, biotite, white mica, calcite, and minor plagioclase, $\mathrm{K}$-feldspar, chlorite, opaque minerals, and epidote. Common minor minerals are opaque minerals, K-feldspar, calcite, white mica, and rarely hornblende. Orientation of elongate quartz grains, lenses of calcite and (or) opaque minerals, and local crystallographic orientation of quartz parallels schistosity. Variable fracturing and granulation of mineral grains are common. Plagioclase is partially recrystallized to white mica and calcite

Chlorite-white mica schists are very fine to fine grained. Local plagioclase porphyroblasts range to $1 \mathrm{~mm}$. Major minerals are quartz, epidoteclinozoisite, plagioclase, and K-feldspar, with lesser calcite and opaque minerals. Minor minerals are biotite and garnet. Local compositional layering parallels schistosity and is defined by bands of quartz alternating with white mica and chlorite

Quartz-biotite schists are mainly fine grained. Plagioclase porphyroblasts range to $1.5 \mathrm{~mm}$. Local major minerals are plagioclase, chlorite, K-feldspar, and epidote, with minor white mica, garnet, calcite, sphene, and garnet. Compositional layering parallels schistosity and is defined by alternating bands of biotite and chlorite or white mica with bands of quartz and plagioclase. Helicitic garnet occurs locally. Biotite is partially recrystallized to chlorite; garnet to biotite and chlorite

Calc-schists and marbles are fine grained and consist of calcitechlorite schist, plagioclase-quartz-epidote schist, marble, and quartz-rich 
marble. Minor minerals are white mica, graphite, opaque minerals, and garnet. Porphyroblasts are principally of quartz, plagioclase, and garnet to $5 \mathrm{~mm}$ and average approximately $1 \mathrm{~mm}$. Rare relict clastic quartz grains are present. In calc-schists, compositional layering parallels schistosity and is generally defined by alternations of quartz and (or) chlorite with variable combinations of plagioclase, calcite, or epidote. Compositional layering in marbles defined by calcite alternating with quartz-rich and (or) chlorite-rich layers. Fracturing and granulation of mineral grains is common. Plagioclase is locally replaced by white mica and calcite; garnet by chlorite

Unit is intensely deformed and exhibits strong schistosity. Schistosity and parallel compositional layering dip gently to moderately north or south, locally defining broad antiforms and synforms. A broad, major antiform occurs in Mount Hayes B-4 quadrangle, subparallel to the Denali Fault. Towards the south, near the Hines Creek and Denali Faults, schistosity and compositional layering dip moderately to steeply south and strike westnorthwest parallel to the faults. In outcrop and thin section, compositional layering and schistosity are generally folded into moderately appressed to tight isoclinal folds with axial planes parallel to the schistosity. Folds deform an older schistosity and compositional layering. Minor folds are generally asymmetrical with south or southwest vergence. Unit was metamorphosed at greenschist facies. Diagnostic lower to middle greenschist facies metamorphic minerals are actinolite, chlorite, white mica, epidote-clinozoisite, and calcite

Unit is faulted against Aurora Peak terrane along the Hines Creek Fault in B-4 and B-5 quadrangles and against Wrangellia terrane along the Denali Fault in B-4 quadrangle. Unit is intruded, from west to east, by granite and granodiorite plutons and by numerous granitic to gabbroic dikes and sills

On strike to the west in the Healy quadrangle, metasedimentary rocks correlated with the fine-grained metasedimentary rocks (jcs) of the Jarvis Creek Glacier subterrane contain Devonian to Mississippian age conodonts (Sherwood and Craddock, 1979; Csejtey and others, 1992). U-Pb isotope analysis of clastic zircons in quartzites (in unit jcs) indicates the protolith was derived, in part, from a lower Proterozoic source rock with radiometric sample ages of 2.0 to $2.3 \mathrm{Ga}$ (Nokleberg and others, 1992a, table 2, localities 22, 23; Aleinikoff and Nokleberg, 1985a,b; Aleinikoff and others, 1987)

Isotopic analyses of the schistose minerals in units jcs and jcv indicate that regional metamorphism and associated penetrative deformation occurred in the Lower to middle Cretaceous. K-Ar isotopic analysis of white mica yields isotopic ages of 106, 107, 115, and $118 \mathrm{Ma}$ (Nokleberg and others, 1992a, table 2, localities 14,16,18,20). These isotopic ages are interpreted as the age of metamorphism, rather than as the age of later cooling, because higher-temperature isotopic systems for higher-grade rocks, in the deepest structural levels of the Yukon-Tanana terrane to the north, yield the same Lower to middle Cretaceous ages (Nokleberg and others, 1989) Devonian) - Chiefly fine-grained, schistose, metavolcanic rocks interlayered with lesser metasedimentary rocks. Metavolcanic rocks consist chiefly of metamorphosed quartz keratophyre, metadacite, and metaandesite with lesser metarhyodacite and metabasalt derived from fine-grained tuffs and flows. 
Metasedimentary rocks chiefly quartz-mica schists and some calc-schists, marble, skarn, and quartzite. Protoliths for metasedimentary rocks are mainly pelite, quartz sandstone, siltstone, marl, and limestone. Metavolcanic rocks occur in layers from about $0.5 \mathrm{~m}$ to a few meters thick and are interlayered with thin to thick layers of metasedimentary rocks. Unit has an estimated structural thickness of a few thousand meters

Metavolcanic rocks generally are characterized by relict microporphyritic texture containing euhedral to subhedral, twinned, and often zoned plagioclase phenocrysts to $4 \mathrm{~mm}$ long in a fine-grained groundmass of quartz, plagioclase, and schistose mica. Poikilitic and clean, relict plagioclase phenocrysts are common. Relict quartz and K-feldspar phenocrysts occur locally. Local resorbed outlines of quartz and feldspar phenocrysts occur. Common metamorphic minerals are quartz, plagioclase, white mica, chlorite, epidote-clinozoisite, and calcite; opaque minerals are present. Sparse metabasalts are composed mainly of actinolite and, locally, epidote and calcite. Minor metamorphic minerals are sericite, chlorite, sphene, biotite, garnet, hornblende, and opaque minerals. Compositional layering parallels schistosity and is defined by bands and lenses of granoblastic quartz and feldspar that alternate with schistose mica. Fracturing and granulation of relict phenocrysts are common with development of augen and augen-shaped aggregates of quartz and feldspar in finer-grained recrystallized matrix. Plagioclase and K-feldspar are partially replaced by sericite, biotite, and actinolite; and hornblende by chlorite

Quartz-mica schists consist of generally fine grained quartz-white mica schist, graphite-quartz-white mica schist, quartz-plagioclase-white micachlorite schist, quartz-white mica-chlorite-plagioclase schist, and calcitechlorite-quartz schist. Minor minerals are calcite, plagioclase, chlorite, graphite, and other opaque minerals, with sparse garnet, hornblende, apatite, sphene, cordierite, zircon, and tourmaline. Sparse porphyroclasts of quartz and feldspar to $2 \mathrm{~mm}$. Relict clastic grains of quartz and feldspar occur locally. Compositional layering parallels schistosity and is generally defined by layers of granoblastic quartz and feldspar that alternate with micaceous layers. Variably distorted, fractured, and granulated quartz and feldspar form augen or augen-shaped aggregates that accompany bent mica. Plagioclase is partially replaced by white mica and calcite; biotite by chlorite

Calc-schists and marbles consist of generally fine grained quartz-white mica-calcite schist, quartz-calcite schist, quartz-plagioclase-white mica-calcite schist, quartz-epidote-clinozoisite schist, quartz-white mica-epidote schist, epidote-plagioclase-actinolite schist, hornblende-biotite-calcite schist, hornblende-plagioclase-calcite schist, marble, and biotite marble. Minor minerals are K-feldspar, biotite, graphite, and opaque minerals. Skarns composed of variable proportions of epidote, garnet, chlorite, calcite, and, locally, clinopyroxene, actinolite, and wollastonite. Porphyroclasts of quartz and plagioclase to $6 \mathrm{~mm}$ long occur locally. Compositional layering generally defined by granoblastic layers of quartz and (or) plagioclase alternating with calcite and combinations of schistose mica, epidote-clinozoisite, amphibole, and opaque minerals. Quartz and calcite grains are locally elongate parallel to schistosity and compositional layering. Plagioclase is partially replaced by 
sericite and calcite; whereas hornblende, actinolite, and biotite are replaced by chlorite

Quartzites are generally composed of sparse flakes to stringers and bands of schistose white mica and (or) biotite and chlorite in fine-grained granoblastic quartz. Weak to strong alignment of elongate quartz grains parallel to schistosity is common. Calcite occurs locally as porphyroclasts and in bands and patches. Local fracturing and granulation is common. Minor minerals are graphite, plagioclase, K-feldspar, and opaque minerals

Unit is intensely deformed and exhibits strong schistosity. Schistosity and parallel compositional layering dips gently to moderately north or south, locally defining broad antiforms and synforms. In outcrop and thin section, compositional layering and schistosity are generally folded into moderately appressed to tight isoclinal folds with axial planes parallel to the schistosity. Unit occurs mainly structurally above fine-grained metasedimentary rocks (jcs). Folds are formed in an older schistosity and are subparallel to compositional layering. Ductile deformation adjacent to major faults has formed locally abundant phyllonites and blastomylonites

Unit metamorphosed at lower greenschist facies. Upper greenschist to lower amphibolite facies minerals are biotite, garnet, cordierite, and hornblende. Lower to middle greenschist facies metamorphic minerals are actinolite, chlorite, graphite, white mica, epidote-clinozoisite, and calcite

Unit occurs in elongate northwest-trending wedge, approximately 50 $\mathrm{km}$ long and as much as $5 \mathrm{~km}$ wide, located principally between the Trident Glacier Fault to the northeast and the Hines Creek Fault to the southwest in the western part of the Mount Hayes quadrangle. Unit is in fault contact with the fine-grained metasedimentary rocks (jcs) of the Jarvis Creek Glacier subterrane to the north and with the Pingston terrane to the south. Unit is intruded by the granodiorite of Molybdenum Ridge (unit Kmo)

$\mathrm{U}-\mathrm{Pb}$ zircon isotopic analysis of samples of metavolcanic rocks (jcv), locally interlayered with metasedimentary rocks, yield ages of 364, 372, and about $375 \mathrm{Ma}$ (Nokleberg and others, 1992a, table 2, localities 12, 15, 28), and are interpreted to indicate eruption in Devonian time

\section{PINGSTON TERRANE—SOUTH OF HINES CREEK FAULT AND NORTH OF NENANA GLACIER AND DENALI FAULTS}

The Pingston terrane (former Hayes Glacier subterrane of Nokleberg and others, 1992b) occurs across the west-central part of the Mount Hayes quadrangle and extends westward into the northwestern and north-central part of the Healy quadrangle. In the Mount Hayes quadrangle, the terrane is bounded to the north by the Jarvis Creek Glacier subterrane along the Hines Creek Fault and to the south by Aurora Peak terrane along the Nenana Glacier Fault. Because of post-1992 analysis, this unit is now identified as a unique, fault-bounded terrane with a stratigraphy and structure that is highly distinct from the structurally adjacent Jarvis Creek Glacier subterrane of the Yukon-Tanana terrane to the north and the Aurora Peak terrane to the south (Nokleberg and others, 1983, 1992b).

The Pingston terrane consists chiefly of highly deformed and structurally interleaved lenses and blocks of metasedimentary and metavolcanic rocks. Large portions of units form a structural mélange with local blastomylonite and mylonite that occur in structurally interleaved lenses and blocks that also 
contain abundant brittle shears (microfaults). Stratigraphic relations are mostly obscured by intense deformation with local random interleaving of stratigraphic units.

Because of the intense deformation, the terrane can only be divided into the following five major units: (1) metagabbro with lesser diabase (Cretaceous?); (2) limestone, calcareous sandstone, and phyllite (Triassic); (3) metabasalt (Paleozoic or Mesozoic?); (4) metasedimentary rock, chiefly phyllite and phyllonite with lesser chert, and intermediate to siliceous metavolcanic rock (Silurian to Devonian); and (5) mafic to siliceous metavolcanic rock with lesser phyllite, metasiltstone, and chert (Devonian, Pennsylvanian, and Triassic). The terrane differs from the Jarvis Creek Glacier subterrane of the YukonTanana terrane to the north in possessing (1) no Devonian metagranitic rocks; (2) a greater abundance of graphitic-rich metasedimentary rocks and fewer metavolcanic rocks; (3) a lower metamorphic grade; (4) a finer metamorphic grain size; and (5) a locally intensely developed, low-grade metamorphic fabric with abundant mylonitic textures.

The protolith of the terrane is interpreted as chiefly continental rise or slope sedimentary rock and associated submarine continental-margin arc rock that were intruded by metagabbro (Nokleberg and others, 1983; Nokleberg and Richter, 2007).

pimg Gabbro and lesser diabase of Mount Moffit (Cretaceous?) - Fine- to mediumgrained, hypidiomorphic granular texture. Two dominant lithologies occur: (1) plagioclase, clinopyroxene, and minor biotite and (2) plagioclase, biotite, local hornblende and minor quartz and K-feldspar. Opaque minerals are locally abundant. Strongly zoned and twinned plagioclase phenocrysts to 1.8 mm occur locally. Clinopyroxene partially replaced by igneous biotite locally. Unit displays light, local alteration of biotite to chlorite and plagioclase to sericite. Unit underlies McGinnis Peak and Mount Moffit in the southwestern Mount Hayes C-5 quadrangle, an area approximately $6 \mathrm{~km}$ across

pil Limestone, calcareous sandstone, and phyllite (Triassic) - Chiefly medium to thick beds of dark- to light-gray, medium- to coarse-grained limestone and local marble; medium-gray, medium-grained calcite-quartz sandstone; and dark-gray phyllite and phyllonite. Lithologies occur in highly deformed and structurally interleaved lenses and blocks in a random order. Local mylonite with extensive brittle shears (microfaults). West of the map area, in the central Healy quadrangle, this unit has yielded Triassic age megafossils and conodonts (Sherwood and Craddock, 1979)

pimb Metabasalt (Triassic to Silurian) - Chiefly fine grained, amygdaloidal, and porphyritic. Unit is medium- to dark-greenish-gray and massive. Contains relict plagioclase phenocrysts to $3 \mathrm{~mm}$ long in a very fine grained, recrystallized groundmass of quartz, actinolite, and epidote. Contains local amygdules filled with chlorite and epidote and local calcite veins. Plagioclase is largely replaced by saussurite. Faint pillow structure occurs locally. Unit locally contains interbedded, dark-gray to black, generally fine grained carbonaceous pelitic phyllite and phyllonite. Unit is over $600 \mathrm{~m}$ thick. Occurs in fault-bounded lens within margin of Aurora Peak terrane in northwest Mount Hayes B-4 quadrangle

pis Metasedimentary rock, chiefly phyllite (Triassic to Silurian)—Chiefly fine grained, pale-yellow, pale-green, and graphitic black metasedimentary phyllite and locally extensive phyllonite and blastomylonite. Predominant lithologies are metachert, quartz-mica phyllite, quartz-calc-phyllite, quartzite, marble, and metavolcanic schist. Protoliths are siltstone, shale, marl, limestone, 
quartz-rich volcanic rocks, and volcanic graywacke. West of the map area, in the central Healy quadrangle, metasedimentary rocks yielded Silurian and Devonian age megafossils (Sherwood and Craddock, 1979)

Intense ductile deformation has obliterated most relict minerals and textures. Local relict meter-scale bedding occurs. Metamorphosed at lower to middle greenschist facies. Diagnostic lower greenschist facies metamorphic minerals are white mica, chlorite, graphite, and calcite. Structural thickness of a few thousand meters is estimated for the unit

Quartz-mica phyllite and phylonite composed of subangular to subrounded quartz clasts in a fine-grained matrix of granular quartz, schistose white mica, and, locally, biotite. Minor minerals are graphite, plagioclase, chlorite, calcite, hematite, opaque minerals, and rare andalusite. Unit contains local, millimeter-scale, quartz-rich, mica-rich, and calcite-rich layers that parallel schistosity. Relict subrounded to subangular clastic quartz grains to $2 \mathrm{~mm}$. Local fine to coarse bands of graphite along schistosity

Quartz-calc-phyllite and phyllonite composed mainly of sparse to abundant relict clasts of quartz and calcite to $2 \mathrm{~mm}$ in matrix, very fine grained quartz, schistose sericite, feldspar, and abundant calcite. Contains local thin graphite-rich layers. Marble is granoblastic to schistose and locally contains minor quartz, white mica, and graphite

Quartzite contains local quartz-mica phyllonite. Compositional layering defined by variably proportioned bands of quartz and white mica and minor biotite, chlorite, and calcite

Metavolcanic schist is composed mainly of relict phenocrysts of plagioclase and lesser quartz and K-feldspar to $3 \mathrm{~mm}$ long, variably fractured and granulated in a matrix of fine granular quartz and schistose sericite. Minor minerals are calcite, chlorite, and opaque minerals. Resorbed outlines of quartz and plagioclase are locally preserved. Plagioclase is partially replaced by sericite

Unit is intensely deformed and exhibits strong schistosity. Schistosity dips moderately to steeply south and strikes west to northwest, generally parallel to the Denali and Hines Creek Faults. Remnant small-scale isoclinal folds occur in outcrop and thin section with axial planes parallel to schistosity that deforms an older, less apparent schistosity. Most folds obliterated by intense deformation along younger schistosity

Unit occurs in fault-bounded wedges. Intruded by gabbro of Mount Moffit (pimg) and by smaller bodies, dikes, and sills of granite and gabbro

piv Mafic to siliceous metavolcanic rock with lesser phyllite, metasiltstone, and chert (Triassic to Silurian) - Chiefly fine grained metavolcanic rock and lesser metasedimentary phyllite and phyllonite. Major lithologies are metamorphosed quartz keratophyre and metaandesite and sparse metalatite, metarhyodacite, metadacite, and metabasalt. Structural thickness estimated to be a few thousand meters. West of map area, in central Healy quadrangle, metasedimentary rocks in this unit have yielded Pennsylvanian and Triassic megafossils (Sherwood and Craddock, 1979). A U-Pb zircon age from a metarhyodacite layer in the terrane is $375 \pm 8 \mathrm{Ma}$ (Aleinikoff and Nokleberg, 1983; Nokleberg and others, 1992a) 
Metavolcanic rocks mainly composed of relict phenocrysts, to $3.5 \mathrm{~mm}$ and averaging about $1.5 \mathrm{~mm}$, of quartz and plagioclase in a groundmass of very fine grained granular quartz, feldspar, abundant schistose chlorite, sericite, K-feldspar, calcite, epidote, actinolite, and sparse biotite. Unit is locally intensely deformed into blastomylonite. Relict plagioclase phenocrysts occur and are commonly fractured and locally recrystallized to augen-shaped aggregates. Unit is intensely deformed into phyllonite. Plagioclase and K-feldspar are partly replaced by white mica; biotite by chlorite

Metasedimentary rocks are chiefly quartz-mica phyllite and phyllonite, quartzite, and quartz-calc phyllite and phyllonite. Protoliths for the metasedimentary rocks are siltstone, sandstone, graywacke, marl, and limestone

Quartz-mica phyllite and phyllonite are predominantly quartz-white mica phyllonite with lesser quartz biotite phyllite and phyllonite, quartzbiotite-K-feldspar phyllite and phyllonite, and white mica-biotite-quartzgraphite phyllite and phyllonite. Common minor minerals are plagioclase, chlorite, calcite, epidote, hematite, andalusite, graphite, chlorite, and opaque minerals. Generally fine grained. Patches of calcite occur locally. Compositional layering, preferred orientation of elongate quartz grains, and grain-size segregation are parallel to schistosity. Compositional layering defined by layers of quartz alternating with layers of mica and, locally, layers of K-feldspar, graphite, and rare andalusite. Local relict rounded quartz pebbles. Unit exhibits local intense granulation and fracturing of quartz and plagioclase. Plagioclase partially replaced by calcite and white mica. Biotite partially replaced by chlorite

Unit intensely recrystallized and ductily deformed. Metamorphosed at lower to middle greenschist facies with local metamorphic biotite. Schistosity dips moderately to steeply south and strikes west to northwest, generally parallel to the Denali and Hines Creek Faults. Remnant, small-scale, isoclinal folds with axial planes are parallel to schistosity that deforms an older schistosity. Most folds obliterated by intense deformation along younger schistosity

Unit occurs in fault-bounded wedges and is intruded by metagabbro of Mount Moffit (pimg) and smaller gabbroic stocks, dikes, and sills. U-Pb zircon isotopic analysis of samples of metavolcanic rocks (piv; interlayered and metasedimentary rocks) in eastern Mount Hayes quadrangle yields an age of $375 \mathrm{Ma}$ (Nokleberg and others, 1992b, table 2, localities 32, 34, 36)

\section{AURORA PEAK TERRANE—SOUTH OF NENANA GLACIER FAULT AND NORTH OF DENALI FAULT}

The Aurora Peak terrane (Nokleberg and others, 1985, 1992b: Nokleberg and Richter, 2007) occurs north of the Denali Fault in the western part of the Mount Hayes quadrangle. The terrane consists of (1) a relatively older unit of metasedimentary rocks, chiefly fine to medium grained and polydeformed calc-schist, marble, quartzite, and pelitic schist (aps) and (2) a relatively younger unit of regionally metamorphosed and penetratively deformed gneissic granitic rocks derived from quartz diorite, granodiorite, granite, gabbro, and diorite (apg). The protoliths for metasedimentary rocks are marl, quartzite, and shale. The Aurora Peak terrane was twice ductility metamorphosed and deformed, once into mylonitic schist during an earlier period of upper amphibolite facies metamorphism and later 
into blastomylonite during a period of middle greenschist facies metamorphism (Nokleberg and others, 1992b). The general parallelism of the schistosity in the gneissic granitic rocks with the Denali and Nenana Glacier Faults suggests that metamorphism and deformation occurred while the faults were active.

Like the Maclaren terrane to the south, the Aurora Peak terrane is interpreted as a displaced fragment of the Kluane schist and the Ruby Range batholith that occur northeast of the Denali Fault 400 $\mathrm{km}$ to the southeast in the Yukon Territory (Nokleberg and others, 1985, 1992b; Nokleberg and Richter, 2007). Although somewhat similar, the Aurora Peak and Mclaren terranes are distinct terranes because of occurrence of the structural mélange of sedimentary and volcanic rocks of the Paleozoic and Cretaceous Windy terrane between the two terranes.

apg Metamorphosed granitic rock (lower Tertiary to middle Cretaceous) — Consists chiefly of stocks, dikes, and sills of metadiorite and minor metamorphosed quartz diorite, granite, granodiorite, and gabbro. Metadiorite and metamorphosed quartz diorite composed of variable amounts of hornblende, clinopyroxene, quartz, and biotite and lesser orthopyroxene, quartz, calcite, sericite, clinozoisite, sphene, apatite, and hematite. Unit is fine to medium grained with relict hypidiomorphic granular texture. Hornblende and plagioclase are variably recrystallized. Hornblende rims clinopyroxene and opaque minerals. Plagioclase partially replaced by white mica

Metagranite and metagranodiorite are fine to medium grained and are composed of variable amounts of biotite and white mica and lesser chlorite, epidote, calcite, sericite, sphene, garnet, andalusite, and actinolite. Relict hypautomorphic granular texture occurs. Metagranodiorite locally contains relict $\mathrm{K}$-feldspar phenocrysts to $7 \mathrm{~mm}$ across. Plagioclase and $\mathrm{K}$-feldspar variably replaced by sericite and minor epidote; clinopyroxene by biotite and chlorite; biotite by chlorite

Unit moderately deformed; exhibits moderate schistosity that dips steeply to vertically and strikes west-northwest. Variably fractured, deformed, and granulated and is metamorphosed to amphibolite facies. Diagnostic amphibolite facies minerals are biotite, garnet, hornblende, and clinopyroxene. Local retrogressive metamorphism indicated by partial replacement of plagioclase and K-feldspar by sericite and epidote; clinopyroxene by biotite and chlorite; and biotite by chlorite

Unit occurs principally in the southern Mount Hayes C-6 quadrangle. Unit is faulted against the Maclaren terrane to the south along the Denali Fault and against the Pingston terrane to the north along the Nenana Glacier Fault. Unit intrudes metamorphosed sedimentary rocks (aps) in stocks, dikes, and sills and is intruded by slightly metamorphosed granite dikes approximately $1 \mathrm{~m}$ wide

In map area, $\mathrm{U}-\mathrm{Pb}$ zircon isotopic analysis of a metadiorite yields a Late Cretaceous age of $71 \mathrm{Ma}$ (Nokleberg and others, 1992a, table 2, locality 38). To the west in the east-central Healy quadrangle, ${ }^{40} \mathrm{Ar} /{ }^{39} \mathrm{Ar}$ isotopic analysis of hornblende in correlative (meta)granitic rocks yields a middle Cretaceous age of $106 \mathrm{Ma}$ (Csejtey and others, 1992, locality 33). These isotopic ages are interpreted as middle Cretaceous to lower Tertiary intrusion of metagranitic rocks in the Aurora Peak terrane

Isotopic analyses of schistose biotite and hornblende in metagranitic rocks are interpreted as forming during uplift and cooling of the Aurora Peak 
terrane in the middle Tertiary. K-Ar isotopic analysis of biotite yields isotopic ages of 18.2, 24.0, and $27 \mathrm{Ma}$ (Nokleberg and others, 1992b, table 2, localities $37,38)$. K-Ar isotopic analysis of hornblende yields an isotopic age of 36.8 Ma (Nokleberg and others, 1992b, table 2, locality 37). Because of the older $\mathrm{U}-\mathrm{Pb}$ zircon isotopic ages and because the Aurora Peak terrane occurs adjacent to the Denali Fault, these K-Ar isotopic dates are interpreted as ages of uplift and cooling of the Aurora Peak terrane during Cenozoic migration along the Denali Fault (Nokleberg and others, 1985, 1989, 1992b)

apmg Metagabbro (lower Tertiary to middle Cretaceous) - Chiefly fine-grained hornblende and plagioclase and minor biotite, clinopyroxene, calcite, chlorite, quartz, white mica, and sphene. Contains local compositional layering defined by alternating bands of schistose biotite and nematoblastic hornblende. Clinopyroxene partially replaced by hornblende and biotite; plagioclase by white mica

aps High-grade metasedimentary schist and carbonate (Triassic to Silurian) Chiefly fine- to medium-grained, mylonitic, calc-schist, marble, quartz-mica schist, and quartzite. Protoliths are marl, limestone, pelite, and sandstone. Structural thickness is estimated at a few thousand meters

Calc-schist consists predominantly of quartz-calcite schist grading to marble but includes some chlorite-calcite schist, plagioclase-calcite schist, biotite-quartz-calcite-hornblende schist, and quartz-epidote-biotite-calcite schist. Minor minerals are white mica, K-feldspar, actinolite, wollastonite, tremolite, clinopyroxene, garnet, graphite, sphene, zoisite, and opaque minerals. Marble locally contains clinopyroxene and garnet. Compositional layering generally consists of alternating quartz and calcite-rich layers with lesser schistose mica. Quartz, plagioclase, and calcite are commonly elongate parallel to schistosity. Variably fractured, granulated, and recrystallized quartz and plagioclase porphyroclasts form augen and augen-shaped aggregates to $1.5 \mathrm{~mm}$ in blastomylonites. Sparse relict clastic quartz grains occur locally. Plagioclase partially replaced by white mica and clinozoisite; clinopyroxene by actinolite and clinozoisite

Quartz-mica schists consist of quartz-white mica schist, white micaquartz schist, quartz-biotite schist, chlorite-white mica-quartz schist, and quartz-chlorite-white mica-graphite schist. Minor minerals are plagioclase, graphite, garnet, calcite, biotite, and opaque minerals. Displays compositional layering defined by alternating quartz-rich and mica-rich layers. Variably distorted, fractured, and granulated quartz and plagioclase commonly form elongate grains parallel to schistosity. Plagioclase is partially recrystallized to white mica

Intense ductile deformation. Schistosity and parallel compositional layering dip steeply to vertically and strike west-northwest, parallel to the Hines Creek, Nenana Glacier, and Denali Faults. Unit is located in the Mount Hayes B-5 and C-5 quadrangles. Small isoclinal folds, defined by folding of an older schistosity, possess axial planes parallel to the dominant and younger schistosity. Local extreme ductile deformation that occurs along schistosity produces mylonitic schist and local blastomylonite

Unit exhibits two periods of metamorphism: (1) an older period at upper amphibolite facies and (2) a younger period at middle greenschist 
facies. Diagnostic upper amphibolite facies minerals are hornblende, clinopyroxene, garnet, biotite, and wollastonite. Diagnostic middle greenschist facies minerals are chlorite, epidote, biotite, white mica, actinolite, and biotite. Lower grade rocks mainly occur along the margins of the terrane near the Denali, Nenana Glacier, and Hines Creek Faults. Retrogressive metamorphism indicated by partial replacement of clinopyroxene by actinolite and clinozoisite; plagioclase by white mica

Unit occurs in a fault-bounded wedge, in the west-central part of the Mount Hayes quadrangle, between the Hines Creek Fault to the northeast, the Nenana Glacier Fault to the north, and the Denali Fault to the south. Unit intruded by stocks, dikes, and sills of metamorphosed and deformed diorite, granodiorite, and granite and by stocks, dikes, and sills of weakly schistose and weakly metamorphosed gabbro. Intrusive contacts are locally faulted

Age of the protolith of the metasedimentary rocks constrained to Silurian through Triassic as determined from conodont fragments of postOrdovician morphotype from one marble body (Nokleberg and others, 1992a, table 1 , locality 7 )

\section{WINDY TERRANE-WITHIN SPLAYS OF DENALI FAULT}

The Windy terrane (Jones and others, 1987; Nokleberg and others, 1985, 1992b; Nokleberg and Richter, 2007) occurs across the Mount Hayes B-4 and B-5 quadrangles within branches of the Denali Fault, north of the Maclaren terrane, and south of the Aurora Peak and Yukon-Tanana terranes. Unlike the adjacent terranes to the north and south, the Windy terrane exhibits primary sedimentary or volcanic textures and structures. Relict sedimentary structures are bedding, graded bedding, and crossbedding. The Windy terrane occurs in narrow slivers that occur discontinuously for several hundred kilometers along the Denali Fault (Jones and others, 1987; Nokleberg and Richter, 2007).

The major units in the structural mélange of the Windy terrane are (1) fault-bounded lenses of Cretaceous flysch and volcanic rocks consisting mainly of argillite; weakly metamorphosed quartz siltstone, quartz sandstone, metagraywacke, and metaconglomerate; and minor andesite and dacite and (2) small to large, fault-bounded lenses of Silurian(?) and Devonian limestone and marl. Estimated structural thickness of the terrane is about 3,000 to 4,000 m.

The two major units occur in narrow, interleaved, fault-bounded lenses. Local intense schistosity strikes northwest parallel to branches of Denali Fault and dips moderately to steeply northeast in the western part of Mount Hayes quadrangle and moderately southwest in the eastern part of quadrangle. Local intense deformation occurs with development of phyllonite and protomylonite. Local abundant brittle shears (microfaults) and fault gouge occur along the southern margin of unit. Unit exhibits incipient greenschist facies metamorphism. Diagnostic minerals are very fine grained chlorite, graphite, sericite, epidote, and actinolite.

The terrane is faulted against the Jarvis Creek Glacier subterrane and the Pingston and Aurora Peak terranes north of the Denali Fault and the Wrangellia and Maclaren terranes south of the Denali Fault. The terrane is intruded by a weakly schistose granite pluton in the Mount Hayes B-4 quadrangle and by small granitic and gabbroic dikes and sills.

The Cretaceous flysch and associated volcanic rocks are interpreted as remnants of the Kahiltna terrane and associated Gravina arc (Stanley and others, 1990; Nokleberg and Richter, 2007). The Silurian(?) and Devonian limestone and marl are interpreted as possibly derived from weakly metamorphosed parts of the Yukon-Tanana terrane to the north. The terrane is a structural mélange of the two major units that have been tectonically mixed during Cenozoic dextral-slip movement along the Denali Fault (Nokleberg and others, 1989; Nokleberg and Richter, 2007). 
The terrane contains one known fragment of a Cretaceous ammonite (Nokleberg and others, 1992a, table 1, locality 8) that was found in float but is interpreted as derived from the unit of flysch and volcanic rocks (J.H. Stout, written commun., 1976). Marl and limestone unit contains Silurian(?) and Devonian megafossils and microfossils (Nokleberg and others, 1992a, table 1, localities 8, 9, 10, 11).

wp $\quad$ Phyllite, argillite, and minor metagraywacke and marl (Cretaceous) - Chiefly medium- to dark-gray, fine-grained phyllite and argillite with lesser mediumgrained metagraywacke, marl, and sparse limestone

Phyllite and argillite are composed of quartz grains, to $0.2 \mathrm{~mm}$, in very fine grained matrix of quartz, chlorite, graphite, and sericite. Contains local plagioclase and quartz-rich silty layers and minor hematite and opaque minerals. Sandy to pebbly siltstone composed of subangular quartz clasts in variable matrix of quartz and sericite and minor calcite, biotite, epidote, actinolite, opaque minerals, and sphene

Marl is mainly black to light gray and well bedded. Exhibits sparse crossbedding and consists mainly of fine-grained phyllitic white mica and calcite enclosing granular quartz and epidote. Major minerals are quartz, calcite, epidote, and white mica. Minor minerals are chlorite, graphite, sphene, tourmaline, and opaque minerals. Unit contains sparse relict angular quartz grains. Unit locally grades into calcareous sandstone. Locally contains sparse quartz pebbles

Unit also contains local fine- to medium-grained, light- to dark-gray limestone composed mainly of calcite and minor dolomite. Local abundant corals. Local sparse grains of quartz and variable amounts of graphite composed of phenocrysts of plagioclase, to $1.0 \mathrm{~mm}$ long, and sparse quartz and biotite in groundmass composed predominantly of plagioclase and minor calcite, epidote, chlorite, white mica, and opaque minerals. Dacite composed of phenocrysts of quartz, plagioclase, and biotite to $1.0 \mathrm{~mm}$ across in groundmass of plagioclase microlites with epidote, white mica, and opaque minerals. Exhibits relict fine-grained igneous textures. Plagioclase and $\mathrm{K}$-feldspar are partially replaced by white mica. Unit also contains minor dacite and volcanic graywacke

wg Metagraywacke and lesser phyllite (Cretaceous) - Chiefly angular clasts of quartz, plagioclase, and, locally, K-feldspar, to $0.4 \mathrm{~mm}$, in matrix of sparse, very fine grained quartz, white mica, and calcite. Plagioclase clasts are locally twinned and zoned. Minor minerals are epidote, biotite, chlorite, sphene, and opaque minerals

Unit also contains local conglomerate composed of medium- to coarse-grained, angular fragments of argillite, silty argillite, chert, and metavolcanic graywacke in a matrix of very fine grained quartz and mica. Relict radiolarians occur in chert clasts. Sandstone composed of fine- to medium-grained, subangular grains of quartz in a fine-grained matrix predominantly of sericite. Plagioclase and K-feldspar are partially replaced by white mica 


\section{MACLAREN TERRANE-SOUTH OF DENALI FAULT AND NORTH OF BROXSON GULCH THRUST}

The Maclaren terrane occurs in the southeast corner of the map, south of the Denali Fault. The terrane consists of two major units: (1) the penetratively deformed and regionally metamorphosed granitic plutonic rocks of the East Susitna batholith to the north and (2) the schist, amphibolite, phyllite, argillite, and metagraywacke of the Maclaren Glacier metamorphic belt to the south (Nokleberg and others, 1982, 1985, 1989, 1992b). The contact between the East Susitna batholith and the Maclaren Glacier metamorphic belt is a faulted intrusive contact named the Meteor Peak Fault (Nokleberg and others, 1982, 1985, 1992b).

The Maclaren terrane is interpreted as a tectonically detached part of a prograde Barrovian-type metamorphic belt and a companion composite continental-margin arc batholith, both intensely metamorphosed and deformed (Smith and Turner, 1973; Nokleberg and others, 1985; Davidson and others, 1992; Nokleberg and Richter, 2007). The increase of metamorphic grade in the Maclaren Glacier metamorphic belt toward the East Susitna batholith indicates metamorphism occurred in response to syntectonic emplacement and overthrusting of the batholith. In addition, similar middle amphibolite facies metamorphism occurs in both the schist and amphibolite unit of the Maclaren Glacier metamorphic belt and the East Susitna batholith, and both contain a parallel or subparallel schistosity. This relation indicates that both were regionally deformed and metamorphosed together during the synkinematic intrusion of the batholith from the Late Cretaceous to the middle Tertiary.

\section{East Susitna Batholith}

mes East Susitna batholith (lower Tertiary and Upper Cretaceous) — South of Denali Fault and north of Meteor Peak Fault. Chiefly gneissose granodiorite and quartz diorite and minor granite. Fine to medium grained, with relict hypidiomorphic granular, seriate, and porphyritic textures containing relict phenocrysts of plagioclase and K-feldspar to $6 \mathrm{~mm}$ across. Relict igneous minerals are plagioclase, quartz, K-feldspar (locally perthitic), biotite, hornblende rimmed by biotite, and clinopyroxene rimmed by biotite and hornblende. Minor zircon and apatite. Relict igneous hornblende rimmed by igneous biotite; clinopyroxene by biotite and minor hornblende. Contains clinopyroxene and hornblende with poikiloblastic texture containing abundant inclusions of feldspar and quartz. Strong undulose extinction occurs in feldspar and quartz augen. Relict igneous plagioclase occurs with complex twinning, normal zoning, and oscillatory zoning. The gneissose granitic plutonic rocks of the East Susitna batholith are derived from diorite, granodiorite, and minor granite and locally grade into units of migmatite, migmatitic schist, and schist and amphibolite. The unit locally contains sparse crosscutting dikes of nonfoliated gabbro, diabase, rhyodacite, and rhyolite

The unit exhibits a single pervasive schistosity that generally strikes northwest to southwest, dips moderately to steeply west, and parallels the younger structures in the schist and amphibolite unit (msh) of the Maclaren Glacier metamorphic belt to the south in the Mount Hayes B-6 quadrangle. Unit is metamorphosed at middle to upper amphibolite facies

Three groups of isotopic ages are determined for the East Susitna batholith: (1) a sample of schistose quartz diorite from the batholith yielded a $\mathrm{U}-\mathrm{Pb}$ zircon age of $70 \mathrm{Ma}$ (Davidson and others, 1992), (2) various and abundant K-Ar ages for metamorphic biotite and hornblende range from 87.4 
to 29.8 Ma (Nokleberg and others, 1992a), and (3) a sample from the Valdez Creek tonalite in the southern part of batholith in the Healy quadrangle yielded U-Pb zircon ages of 64 to $60 \mathrm{Ma}$ (Davidson and others, 1992; Ridgway and others, 2002). Several observations indicate intrusion of the batholith during regional deformation (syntectonic intrusion) (Nokleberg and others, 1985, 1992b): (1) occurrence of a parallel regional metamorphic fabric formed at amphibolite facies in both the East Susitna batholith and the structurally subjacent Maclaren metamorphic belt (described below) and (2) overlapping $\mathrm{U}-\mathrm{Pb}$ zircon intrusive ages and the older ranges of hornblende and biotite metamorphic ages (Upper Cretaceous and lower Tertiary)

Maclaren Glacier Metamorphic Belt

The Maclaren Glacier metamorphic belt occurs to the south of the East Susitna batholith (south of Meteor Peak Fault and north of Broxson Gulch Thrust) and is a pro-grade Barrovian-type metamorphic belt. From south to north, the major units are (1) Upper Jurassic or older argillite and metagraywacke; (2) phyllite; and (3) quartz-mica schist, calc-schist, and amphibolite (Nokleberg and others, 1985, 1992b). Contacts between the three major units are faults exhibiting abundant brittle shears (microfaults) and abrupt changes of metamorphic facies at each surface.

The Maclaren Glacier metamorphic belt is ductility deformed into protomylonite and phyllonite in the argillite and metagraywacke unit, phyllonite in the phyllite unit, and mylonitic schist in the quartzmica schist, calc-schist, and amphibolite unit. A general increase in metamorphic grade occurs from the argillite and metagraywacke unit in the south to the quartz-mica schist, calc-schist, and amphibolite unit in the north, grading from lower greenschist facies in the argillite and metagraywacke unit to lower or middle amphibolite facies metamorphism in the quartz-mica schist, calc-schist, and amphibolite unit (Nokleberg and others, 1985, 1989). metasedimentary schist. Unit consists mainly of quartz-mica schist, amphibolite, and calc-schist. Protoliths are chiefly pelite, sandstone, graywacke, and minor marl, andesite, and gabbro. Grain size is 0.1 to $0.3 \mathrm{~mm}$. Estimated structural thickness is about $6,700 \mathrm{~m}$

Quartz-mica schist consists of fine-grained white mica-quartz schist, biotite-white mica-quartz schist, garnet-white mica-quartz schist, biotitequartz schist, plagioclase-white mica-quartz schist, and plagioclase-chloritequartz-white mica schist. Amphibolite, derived from marl, is composed of schistose hornblende, garnet, biotite, quartz, plagioclase, and calcite. Unit is metamorphosed to amphibolite facies

Unit is intensely deformed with a strong schistosity. Two generations of isoclinal folds occur with opposite vergences, with axial planes parallel to schistosity. Older generation folds generally show north vergence, whereas younger generation folds generally show south vergence

A latest Cretaceous to lower Tertiary age of regional metamorphism for the Maclaren Glacier metamorphic belt is indicated by (1) K-Ar hornblende and biotite ages ranging from 64.1 to 28.5 Ma (Nokleberg and others, 1992a) and (2) ${ }^{40} \mathrm{Ar} /{ }^{39} \mathrm{Ar}$ plateau ages of 69 to $60 \mathrm{Ma}$ for metamorphic biotite in the highest-grade part of the metamorphic belt (schist and amphibolite unit) in the Healy quadrangle (Davidson and others, 1992; Ridgway and others, 2002). The latter data indicate that regional 
metamorphism and deformation of the metamorphic belt ended at about $62 \mathrm{Ma}$ (Davidson and others, 1992; Ridgway and others, 2002)

\section{WRANGELLIA TERRANE}

The Wrangellia terrane occurs in the southeast corner of the map and is faulted against the Maclaren terrane to the north along the Broxson Gulch thrust.

In the map area, the Wrangellia terrane contains only three units: (1) a unit of ultramafic plutonic rock; (2) a unit of gabbro and metagabbro; and (3) the Slana Spur Formation. The unit of ultramafic plutonic rock may be fault-bounded slices juxtaposed along the Broxson Gulch thrust or may be derived from the base of the Wrangellia terrane. The unit of gabbro and metagabbro may have similar origins or may be part of the late Paleozoic Skolai island arc that formed the volcanoclastic and volcanic rocks of the Slana Spur Formation or may be related to extrusion of basalt that formed the Middle to Upper Triassic Nikolai Greenstone.

In the map area, three major geologic events occurred in the origin and evolution of the Wrangellia terrane. The first event was formation of the Upper Paleozoic submarine volcanic, sedimentary, and plutonic rocks of the Skolai arc (Bond, 1973, 1976; Richter and Jones, 1973; Nokleberg and others, 1985; Barker and Stern, 1986; Nokleberg and Richter, 2007). The second event is interpreted as back-arc rifting that formed the Upper Triassic Nikolai Greenstone and associated gabbro dikes and cumulate mafic and ultramafic sills (Richter and Jones, 1973; Jones and others, 1987; Nokleberg and others, 1985; Nokleberg and Richter, 2007). The third event was formation of a marginal flysch basin in which the Upper Jurassic and Lower Cretaceous argillite, graywacke, conglomerate, and andesite of the Gravina-Nutzotin belt was deposited onto the northern edge of the Wrangellia terrane (Berg and others, 1972; Richter and Jones, 1973; Nokleberg and others, 1985; Nokleberg and Richter, 2007).

wrum Ultramafic plutonic rock (Cretaceous to Triassic?) —Chiefly dunite, olivineclinopyroxene cumulate, serpentinite, metagabbro, and metadiabase. Ultramafic rocks contain both cumulate and metamorphic textures and are interpreted as a dismembered alpine peridotite. Relations of the mafic rocks to the ultramafic rocks is unclear. Relatively younger mafic dikes locally intrude the alpine peridotite and may be part of the unit of gabbro, diabase, and metagabbro (wrgm) that intrudes Upper Triassic and older rocks throughout the Wrangellia terrane. Structural thickness is estimated at about 1,500 m. Olivine is partially to completely replaced by serpentine; pyroxene, hornblende, and biotite by chlorite

wrgb Gabbro and metagabbro (Cretaceous to Triassic?)-Metagabbro composed principally of fine- to medium-grained, diabasic-texture hornblende metagabbro and minor hornblende-clinopyroxene metagabbro and clinopyroxene metagabbro. A relict fine- to medium-grained, hypidiomorphic granular and lesser subophitic texture occurs locally. Relict minerals are hornblende, plagioclase, clinopyroxene, olivine, quartz, biotite, ilmenite, and opaque minerals. Metagabbro and metadiabase are variably metamorphosed at lower greenschist facies. Relict minerals are plagioclase, clinopyroxene, and hornblende. Metadiabase is composed of hornblende-plagioclase metadiabase and clinopyroxene-plagioclase metadiabase

wrs Slana Spur Formation (Lower Permian to Middle Pennsylvanian) - Chiefly calcareous and volcaniclastic rocks composed of a thick sequence of marine calcareous and noncalcareous volcaniclastic rocks and lesser limestone, tuff, and volcanic breccia. Occurs in the southeastern and south-central parts of the 
Mount Hayes quadrangle. Ages of megafossils and microfossils in both members of formation, mainly brachiopods, corals, and foraminifers, range from Middle Pennsylvanian through Lower Permian (Nokleberg and others, 1992a, table 1, localities 13-16, 52-57, 59-63, 65-69, 71-72, 76, 86, 107108). Thickness of unit is estimated at 700 to $1,400 \mathrm{~m}$. Unit exhibits lower greenschist facies metamorphism and is locally intruded by diabase and andesite dikes, sills, and small plutons

\section{References Cited}

Aleinikoff, J.N., 1984a, Age and origin of metaigneous rocks from terranes north and south of the Denali fault, Mt. Hayes quadrangle, east-central Alaska [abs.]: Geological Society of America Abstracts with Programs, v. 16, no. 5, p. 266.

Aleinikoff, J.N., 1984b, Early Proterozoic metavolcanic rocks in the Jarvis Creek Glacier tectonostratigraphic terrane, Mount Hayes C-6 quadrangle, eastern Alaska Range, Alaska, in Reed, K.M., and Bartsch-Winkler, S.R., The United States Geological Survey in Alaska-Accomplishments during 1982: U.S. Geological Survey Circular 939, p. 40-44.

Aleinikoff, J.N., Dusel-Bacon, C., and Foster, H.L., 1986, Geochronology of augen gneiss and related rocks, Yukon-Tanana terrane, east-central Alaska: Geological Society of America Bulletin, v. 97, p. 626-637.

Aleinikoff, J.N., Dusel-Bacon, C., Foster, H.L., and Nokleberg, W.J., 1987, Pb-isotope fingerprinting of tectonostratigraphic terranes, east-central Alaska: Canadian Journal of Earth Sciences, v. 24, p. 20892098.

Aleinikoff, J.N., and Nokleberg, W.J., 1983, Uranium-lead geochronology of a metarhyodacite from the Pingston terrane, Mount Hayes C-6 quadrangle, eastern Alaska Range, Alaska, in Coonrad, W.L., and Elliott, R.L., eds., The United States Geological Survey in Alaska-Accomplishments during in 1981: U.S. Geological Survey Circular 868, p. 73-75.

Aleinikoff, J.N., and Nokleberg, W.J., 1985a, Age of Devonian igneous-arc terranes in the northern Mount Hayes quadrangle, eastern Alaska Range, Alaska, in Bartsch-Winkler, Susan, ed., The United States Geological Survey in Alaska-Accomplishments during 1984: U.S. Geological Survey Circular 967, p. 44-49.

Aleinikoff, J.N., and Nokleberg, W.J., 1985b, Age of intrusion and metamorphism of a granodiorite in the Lake George terrane, northeastern Mount Hayes quadrangle, Alaska, in Bartsch-Winkler, Susan, and Reed, K.M., eds., The United States Geological Survey in Alaska-Accomplishments during 1983: U.S. Geological Survey Circular 945, p. 62-65.

Barker, F., and Stern, T.W., 1986, An arc-root complex of Wrangellia, Eastern Alaska Range [abs.]: Geological Society of America Abstracts with Programs, v. 18, p. 534.

Berg, H.C., Jones, D.L., and Richter, D.H., 1972, Gravina-Nutzotin belt-Tectonic significance of an upper Mesozoic sedimentary and volcanic sequence in southern and southeastern Alaska, in Geological Survey research 1972: U.S. Geological Survey Professional Paper 800-D, p. D1-D24.

Black, L.P., Kamo, S.L., Allen, C.M., Davis, D.W., Aleinikoff, J.N., Valley, J.W., Mundil, R., Campbell, I.H., Korsuch, R.J., Williams, I.S., and Foudoulis, C, 2004, Improved ${ }^{206} \mathrm{~Pb} /{ }^{238} \mathrm{U}$ microprobe geochronology by the monitoring of a trace-element-related matrix effect; SHRIMP, ID-TIMS, ELA-ICP-MS and oxygen isotope documentation for a series of zircon standards: Chemical Geology, v. 205, p. 115-140.

Bond, G.C., 1973, A late Paleozoic volcanic arc in the eastern Alaska Range, Alaska: Journal of Geology, v. 81, p. 557-575. 
Bond, G.C., 1976, Geology of the Rainbow Mountain-Gulkana Glacier area, eastern Alaska Range, with emphasis on upper Paleozoic strata: Alaska Division of Geological and Geophysical Surveys Geologic Report 45, $47 \mathrm{p}$.

Brewer, W.J., 1982, Stratigraphy, structure, and metamorphism of the Mount Deborah area, central Alaska Range, Alaska: Madison, University of Wisconsin, Ph.D. dissertation, scale 1:63,360, 318 p.

Carter, L.D., and Galloway, J.P., 1978, Preliminary geologic maps of the proposed natural gas pipeline route in the Tanana River valley, Alaska: U.S. Geological Survey Open-File Report 78-794, 3 sheets, scale $1: 125,000,26 \mathrm{p}$.

Csejtey, B., Jr., Mullen, M.W., Cox, D.P., and Stricker, G.D., 1992, Geology and geochronology of the Healy quadrangle, south-central Alaska: U.S. Geological Survey Miscellaneous Investigation Series I-1961, scale 1:250,000, $63 \mathrm{p}$.

Dashevsky, S.S., Schaefer, C.F., and Hunter, E.N., 2003, Bedrock geologic map of the Delta mineral belt, Tok mining district, Alaska: Alaska Division of Geological and Geophysical Surveys, Professional Report 122, 2 plates, scale 1:63,360, 122 p.

Davidson, C., Hollister, S.M., and Schmid, S.M., 1992, Role of melt in the formation of a deep-crustal compressive shear zone-The Maclaren Glacier metamorphic belt, south-central Alaska: Tectonics, v. 11, p. 348-359.

Dusel-Bacon, C., and Aleinikoff, J.N., 1985, Petrology and tectonic significance of augen gneiss from a belt of Mississippian granitoids in the Yukon-Tanana terrane, east-central Alaska: Geological Society of America Bulletin, v. 96, p. 411-425.

Dusel-Bacon, C., Hopkins, M.J., Mortensen, J.K., Dashevsky, S.S., Bressler, J.R., and Day, W.C., 2006, Paleozoic tectonic and metallogenic evolution of the pericratonic rocks of east-central Alaska and adjacent Yukon Territory, in Colpron, Maurice, and Nelson, J.L., eds., Paleozoic evolution and metallogeny of pericratonic terranes at the ancient Pacific margin of North America, Canadian and Alaskan Cordillera: Geological Association of Canada Special Paper 45, p. 25-74.

Fuis, G.S., Moore, T.E., Plafker, G., Brocher, T.M., Fisher, M.A., Mooney, W.D., Nokleberg, W.J., Page, R.A., Beaudoin, B.C.,Christensen, N.I., 2008, Trans-Alaska Crustal Transect and continental evolution involving subduction underplating and synchronous foreland thrusting: Geology, v. 36, p. 267-270.

Gilbert, W.G., 1977, General geology of the Healy D-1 and southern Fairbanks A-1 quadrangles, Alaska: Alaska Division of Geological and Geophysical Surveys, Open-file Report 105, scale $1: 63,360$.

Holmes, G.W., and Benninghoff, W.S., 1957, Terrain study of the Army Test Area, Fort Greely, Alaska: U.S. Geological Survey, Military Geologic Branch, v. 1, 287 p.; v. 2, maps.

Jones, D.L., Silberling, N.J., Coney, P.J., and Plafker, G., 1987, Lithotectonic terrane map of Alaska: U.S. Geological Survey Miscellaneous Field Studies Map MF-1874-A, 1 sheet, scale 1:2,500,000.

Ludwig, K.R., 2003, Isoplot/Ex version 3.00-A geochronological toolkit for Microsoft Excel: Berkeley Geochronology Center Special Publication, no. 4, 73 p. (Software available at http://www.bgc.org/isoplot_etc/squid.html.)

Ludwig, K.R., 2009, Squid 2, version 2.50-A user's manual: Berkeley Geochronology Center. (Software available at http://www.bgc.org/isoplot_etc/squid.html.)

Nokleberg, W.J., Albert, N.R.D., Bond, G.C., Herzon, P.L., Miyaoka, R.T., Nelson, W.H., Richter, D.H., Smith, T.E., Stout, J.H., Yeend, W., and Zehner, R. E., 1982, Geologic map of the southern part of the Mount Hayes quadrangle, Alaska: U.S. Geological Survey Open-File Report 82-52, scale $1: 250,000,26 \mathrm{p}$. 
Nokleberg, W.J., and Aleinikoff, J.N., 1985, Summary of stratigraphy, structure, and metamorphism of Devonian igneous-arc terranes, northeastern Mount Hayes quadrangle, eastern Alaska Range, in Bartsch-Winkler, Susan, ed., The United States Geological Survey in Alaska-Accomplishments during 1984: U.S. Geological Survey Circular 967, p. 66-71.

Nokleberg, W.J., Aleinikoff, J.N., Dutro, J.T., Jr., Lanphere, M.A., Silberling, N.J., Silva, S.R., Smith, T.E., and Turner, D.L., 1992a, Map, tables, and summary of fossil and isotopic age data, Mount Hayes quadrangle, eastern Alaska Range, Alaska: U.S. Geological Survey Miscellaneous Field Studies Map MF-1996-D, 1 sheet, scale 1:250,000, 43 p.

Nokleberg, W.J., Aleinikoff, J.N., and Lange, I.M., 1986, Cretaceous deformation and metamorphism in the northeastern Mount Hayes quadrangle, eastern Alaska Range, in Bartsch-Winkler, Susan, and Reed, K.M., eds., Geologic studies in Alaska by the U.S. Geological Survey during 1985: U.S. Geological Survey Circular 978, p. 64-69.

Nokleberg, W.J., Aleinikoff, J.N., Lange, I.M., Silva, S.R., Miyaoka, R.T., Schwab, C.E., and Zehner, R.E., 1992b, Preliminary geologic map of the Mount Hayes quadrangle, eastern Alaska Range, Alaska: U.S. Geological Survey Open-File Report 92-594, 1 sheet, scale 1:250,000, 39 p.

Nokleberg, W.J., Foster, H.L., and Aleinikoff, J.N., 1989, Geology of the northern Copper River Basin, eastern Alaska Range, and southern Yukon-Tanana Basin, southern and east-central Alaska, in Nokleberg, W.J., and Fisher, M.A., eds., Alaskan Geological and Geophysical Transect: Field Trip Guidebook T104, 28th International Geological Congress, p. 34-63.

Nokleberg, W.J., Jones, D.L., and Silberling, N.J., 1985, Origin and tectonic evolution of the Maclaren and Wrangellia terranes, eastern Alaska Range, Alaska: Geological Society of America Bulletin, v. 96, p. 1251-1270.

Nokleberg, W.J., and Richter, D.H., 2007, Origin of narrow terranes and adjacent major terranes occurring along the Denali fault in the Eastern and Central Alaska Range, Alaska, in Tectonic growth of a collisional continental margin - Crustal evolution of southern Alaska: Geological Society of America Special Paper 431, p. 129-154.

Nokleberg, W.J., Schwab, C.E., Miyaoka, R.T., and Buhrmaster, C.L., 1983, Stratigraphy, petrology, and structure of the Pingston terrane, Mount Hayes C-6 and C-5 quadrangles, eastern Alaska Range, Alaska, in Coonrad, W.L., and Elliott, R.L., eds., The United States Geological Survey in AlaskaAccomplishments during 1981: U.S. Geological Survey Circular 868, p. 70-73.

Richter, D.H., and Jones, D.L., 1973, Structure and stratigraphy of the eastern Alaska Range, Alaska: American Association of Petroleum Geologists, Arctic Geology, Memoir 19, p. 408-420.

Ridgway, K.D., Trop, J.M., Nokleberg, W.J., Davidson, C.M., and Eastham, K.R., 2002, Mesozoic and Cenozoic tectonics of the eastern and central Alaska Range, progressive basin development and deformation in a suture zone: Geological Society of America Bulletin, v. 114, no. 12, p. 1480-1504.

Sherwood, K.W., and Craddock, C., 1979, General geology of the central Alaska Range between the Nenana River and Mount Deborah: Alaska Division of Geological and Geophysical Surveys OpenFile Report 116, 2 plates, scale 1:63,360, 22 p.

Smith, T.E., and Turner, D.L., 1973, Geochronology of the Maclaren metamorphic belt, south-central Alaska-A progress report: Isochron/West, no. 7, p. 21-25.

Stacey, J.S., and Kramers, J.D., 1975, Approximation of terrestrial Pb isotope composition by a twostage model: Earth and Planetary Science Letters, v. 26, p. 207-222.

Stanley, W.D., Labson, V.F., Csejtey, B., Jr., Nokleberg, W.J., Fisher, M.A., and Long, C.I., 1990, The Denali fault system and Alaska Range of Alaska-Evidence for suturing and thin-skinned tectonics from magnetotellurics: Geological Society of America Bulletin, v. 102, p. 160-173. 
Steiger, R.H., and Jäger, E., 1977, Subcommission on geochronology, convention on the use of decay constants in geo- and cosmochronology: Earth and Planetary Science Letters, v. 36, p. 359-362.

U.S. Army Corps of Engineers, 1960, Terrain study of the Delta River region, Alaska: Department of the Army, Engineering Intelligence Study 264, 46 p.

Veenstra, E., Christensen, D.H., Abers, G.A., and Ferris, A., 2006, Crustal thickness variation in southcentral Alaska: Geology, v. 34, no. 9, p. 781-784.

Wahrhaftig, C., Turner, D.L., Weber, F.R., and Smith, T.E., 1975, Nature and timing of movement on Hines Creek strand of Denali fault system, Alaska: Geology, v. 3, no. 8, p. 463-466.

Weber, F.R., 1971, Preliminary engineering geologic maps of the proposed Trans-Alaska pipeline route, Mount Hayes quadrangle: U.S. Geological Survey Open-File Map 493, 2 sheets, scale 1:125,000.

Williams, I.S., 1998, Chapter 1, U-Th-Pb geochronology by ion microprobe, in McKibben, M.A., Shanks, W.C., III, and Ridley, W.I., eds., Applications of microanalytical techniques to understanding mineralizing processes: Reviews of Economic Geology, v. 7, p. 1-35.

Woodward-Lundgren and Associates, 1974, Summary report basis for pipeline design for active-fault crossings for the Trans-Alaska Pipeline System: Houston, Texas, Alyeska Pipeline Service Company, $115 \mathrm{p}$. 

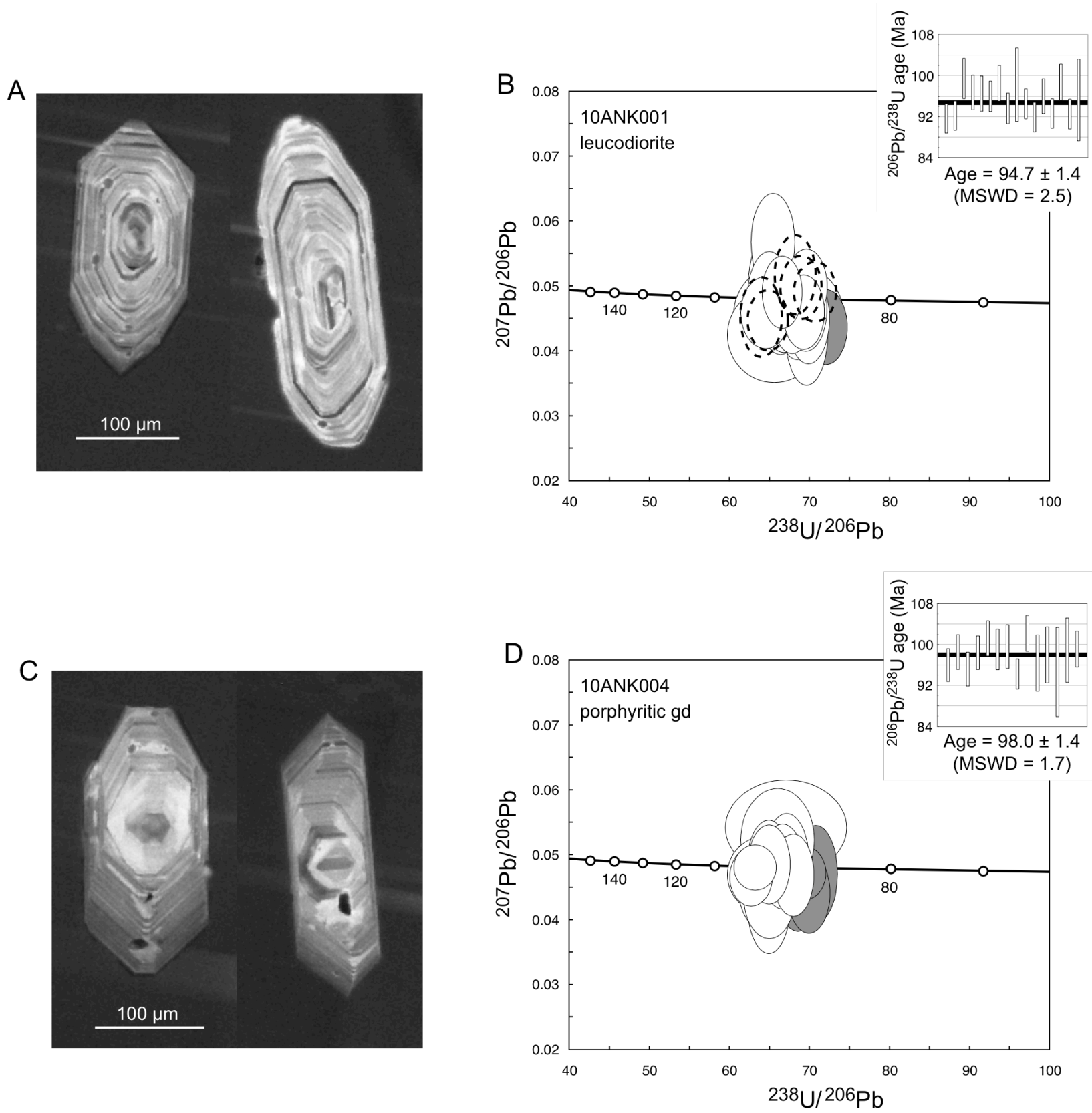

Figure 1. Representative images and SHRIMP U-Pb data from zircon from plutonic rocks near the Hines Creek fault zone. White-filled error-ellipses are U-Pb data used to calculate the weighted average age (see inset). Gray error ellipses are U-Pb data excluded from age calculation. $A, \mathrm{CL}$ images of zircon from $10 \mathrm{ANK} 001$ (leucodiorite). B, Tera-Wasserburg plot of SHRIMP data from 10ANK001. Only data from cores used in age calculation. Unfilled ellipses with dashed borders are data from dark (in $\mathrm{CL}$ ) tips of grains. $C, \mathrm{CL}$ images of zircon from 10ANK004 CL images of zircon from 10ANK004 (porphyritic granodiorite). D, Tera-Wasserburg plot of SHRIMP data from 10ANK004 (porphyritic granodiorite). 
Table 1. SHRIMP U-Th-Pb data for zircon from two granitic plutons near the Hines Creek Fault, Alaska.

[---, not measured]

\begin{tabular}{|c|c|c|c|c|c|c|c|c|c|c|c|}
\hline \multirow{2}{*}{$\begin{array}{l}\text { Sample } \\
\text { (Location) }\end{array}$} & \multirow{2}{*}{$\begin{array}{c}\text { Measured } \\
{ }^{204} \mathrm{~Pb} \\
{ }^{206} \mathrm{~Pb}\end{array}$} & \multirow{2}{*}{$\begin{array}{l}\text { Measured } \\
{ }^{207} \mathrm{~Pb} \\
{ }^{206} \mathrm{~Pb}\end{array}$} & \multirow{2}{*}{$\begin{array}{c}\% \\
\text { common } \\
{ }^{206} \mathrm{~Pb}\end{array}$} & \multirow[b]{2}{*}{$\begin{array}{c}\mathrm{U} \\
(\mathrm{ppm})\end{array}$} & \multirow[b]{2}{*}{$\mathrm{Th} / \mathrm{U}$} & \multicolumn{2}{|c|}{ Ages (Ma) } & \multirow[b]{2}{*}{$\frac{{ }^{238} \mathrm{U}^{4}}{{ }^{206} \mathrm{~Pb}}$} & \multirow[b]{2}{*}{$\begin{array}{l}\mathrm{err}^{3} \\
(\%)\end{array}$} & \multirow[b]{2}{*}{$\frac{{ }^{207} \mathrm{~Pb}^{4}}{{ }^{206} \mathrm{~Pb}}$} & \multirow[b]{2}{*}{$\begin{array}{l}\mathrm{err}^{3} \\
(\%)\end{array}$} \\
\hline & & & & & & $\frac{{ }^{206} \mathrm{~Pb}^{2}}{{ }^{238} \mathrm{U}}$ & $\mathrm{err}^{3}$ & & & & \\
\hline 10ANK001-1ozc & -0.000026 & 0.0458 & -0.27 & 1066 & 0.216 & 99.4 & 2 & 64.5 & 1.9 & 0.0462 & 4.9 \\
\hline 10ANK001-2ozc & 0.000123 & 0.0459 & -0.25 & 856 & 0.246 & 89.4 & 1 & 72.0 & 1.5 & 0.0440 & 5.3 \\
\hline 10ANK001-3ozc & -0.000028 & 0.0498 & 0.25 & 1093 & 0.154 & 91.7 & 1 & 69.6 & 1.5 & 0.0502 & 4.6 \\
\hline 10ANK001-4ozc & 0.000138 & 0.0488 & 0.12 & 810 & 0.216 & 92.2 & 1 & 69.5 & 1.5 & 0.0468 & 5.7 \\
\hline 10ANK001-5uzt & 0.000147 & 0.0477 & -0.04 & 1086 & 0.215 & 100 & 2 & 64.0 & 1.6 & 0.0455 & 5.5 \\
\hline 10ANK001-6ozc & -0.000085 & 0.0557 & 0.98 & 779 & 0.211 & 96.7 & 2 & 65.4 & 1.7 & 0.0570 & 5.3 \\
\hline 10ANK001-7ozc & 0.000149 & 0.0500 & 0.25 & 539 & 0.193 & 96.5 & 2 & 66.3 & 1.7 & 0.0478 & 6.8 \\
\hline 10ANK001-8ozc & 0.000138 & 0.0514 & 0.43 & 1363 & 0.178 & 96.0 & 1 & 66.6 & 1.5 & 0.0493 & 4.6 \\
\hline 10ANK001-9uzt & -0.000038 & 0.0445 & -0.44 & 1894 & 0.111 & 99.1 & 2 & 64.8 & 1.6 & 0.0450 & 4.2 \\
\hline 10ANK001-10ozc & --- & 0.0482 & 0.03 & 568 & 0.290 & 98.5 & 2 & 64.9 & 1.7 & 0.0482 & 6.2 \\
\hline 10ANK001-11ozc & -0.000187 & 0.0440 & -0.49 & 610 & 0.196 & 93.6 & 1 & 68.4 & 1.5 & 0.0468 & 6.8 \\
\hline 10ANK001-12ozc & 0.000045 & 0.0435 & -0.57 & 650 & 0.198 & 98.2 & 4 & 65.6 & 3.6 & 0.0428 & 6.9 \\
\hline 10ANK001-13ozc & 0.000126 & 0.0481 & 0.03 & 1072 & 0.243 & 94.5 & 1 & 67.8 & 1.5 & 0.0463 & 5.6 \\
\hline 10ANK001-14uzt & --- & 0.0501 & 0.28 & 1317 & 0.136 & 92.6 & 1 & 68.9 & 1.5 & 0.0501 & 4.0 \\
\hline 10ANK001-15ozc & 0.000044 & 0.0460 & -0.24 & 635 & 0.215 & 91.9 & 1 & 69.8 & 1.5 & 0.0453 & 6.3 \\
\hline 10ANK001-16uzt & -0.000045 & 0.0487 & 0.12 & 2008 & 0.095 & 90.4 & 1 & 70.7 & 1.5 & 0.0494 & 3.8 \\
\hline 10ANK001-17ozc & --- & 0.0472 & -0.09 & 675 & 0.191 & 96.0 & 2 & 66.7 & 1.7 & 0.0472 & 6.1 \\
\hline 10ANK001-18ozc & 0.000130 & 0.0482 & 0.04 & 910 & 0.253 & 92.6 & 1 & 69.2 & 1.5 & 0.0463 & 5.0 \\
\hline 10ANK001-19uzt & 0.000370 & 0.0574 & 1.20 & 1192 & 0.142 & 93.4 & 1 & 68.2 & 1.5 & 0.0520 & 4.8 \\
\hline 10ANK001-20ozc & --- & 0.0477 & -0.04 & 717 & 0.181 & 98.7 & 2 & 64.9 & 1.7 & 0.0477 & 9.9 \\
\hline 10ANK001-21ozc & 0.000147 & 0.0452 & -0.34 & 618 & 0.197 & 92.5 & 1 & 69.6 & 1.5 & 0.0430 & 7.5 \\
\hline 10ANK001-22ozc & 0.000291 & 0.0501 & 0.27 & 644 & 0.179 & 95.2 & 4 & 67.4 & 4.2 & 0.0458 & 7.3 \\
\hline 10ANK004-1ozc & 0.000159 & 0.0508 & 0.36 & 1011 & 0.304 & 96.0 & 2 & 66.6 & 1.6 & 0.0485 & 5.5 \\
\hline 10ANK004-2ozc & 0.000040 & 0.0494 & 0.18 & 664 & 0.274 & 98.5 & 2 & 64.9 & 1.7 & 0.0488 & 5.6 \\
\hline 10ANK004-3ozc & 0.000085 & 0.0506 & 0.34 & 636 & 0.269 & 95.2 & 2 & 67.1 & 1.7 & 0.0493 & 6.0 \\
\hline 10ANK004-4ozc & -0.000060 & 0.0479 & -0.01 & 939 & 0.278 & 98.4 & 2 & 65.0 & 1.6 & 0.0488 & 5.0 \\
\hline 10ANK004-5ozc & -0.000042 & 0.0477 & -0.04 & 684 & 0.303 & 101 & 2 & 63.2 & 1.7 & 0.0483 & 2.9 \\
\hline 10ANK004-6ozc & --- & 0.0444 & -0.43 & 744 & 0.351 & 92.0 & 1 & 69.9 & 1.5 & 0.0444 & 5.6 \\
\hline 10ANK004-7ozc & -0.000038 & 0.0433 & -0.59 & 736 & 0.262 & 99.0 & 2 & 64.9 & 2.0 & 0.0438 & 5.9 \\
\hline 10ANK004-8ozc & 0.000069 & 0.0462 & -0.23 & 875 & 0.259 & 99.6 & 2 & 64.5 & 2.1 & 0.0452 & 5.9 \\
\hline 10ANK004-9ozc & -0.000034 & 0.0467 & -0.15 & 952 & 0.285 & 94.2 & 1 & 68.0 & 1.5 & 0.0472 & 5.4 \\
\hline 10ANK004-10ozc & -0.000145 & 0.0448 & -0.41 & 608 & 0.273 & 102 & 2 & 62.7 & 1.7 & 0.0469 & 3.8 \\
\hline 10ANK004-11ozc & --- & 0.0526 & 0.58 & 518 & 0.298 & 96.4 & 3 & 66.0 & 2.8 & 0.0526 & 6.1 \\
\hline 10ANK004-12ozc & --- & 0.0465 & -0.18 & 725 & 0.305 & 97.9 & 3 & 65.4 & 2.8 & 0.0465 & 5.3 \\
\hline 10ANK004-13ozc & 0.000152 & 0.0471 & -0.10 & 804 & 0.273 & 93.7 & 1 & 68.5 & 1.5 & 0.0449 & 5.7 \\
\hline 10ANK004-14ozc & -0.000158 & 0.0521 & 0.53 & 623 & 0.277 & 94.7 & 4 & 67.1 & 4.6 & 0.0544 & 5.5 \\
\hline 10ANK004-15ozc & -0.000059 & 0.0464 & -0.20 & 975 & 0.265 & 98.9 & 3 & 64.8 & 3.2 & 0.0472 & 5.2 \\
\hline 10ANK004-16ozc & 0.000128 & 0.0492 & 0.18 & 579 & 0.260 & 90.6 & 1 & 70.7 & 1.6 & 0.0473 & 6.4 \\
\hline 10ANK004-17ozc & 0.000144 & 0.0496 & 0.22 & 752 & 0.265 & 92.3 & 1 & 69.4 & 1.5 & 0.0475 & 3.5 \\
\hline 10ANK004-18ozc & 0.000160 & 0.0459 & -0.26 & 524 & 0.245 & 99.1 & 2 & 64.9 & 1.7 & 0.0436 & 7.9 \\
\hline
\end{tabular}

${ }^{1}$ Samples analyzed September 2011 by USGS/Stanford SHRIMP-RG. Abbreviations: ozc, oscillatory-zoned core; uzt, unzoned tip.

${ }^{2}{ }^{206} \mathrm{~Pb} /{ }^{238} \mathrm{U}$ ages corrected for common $\mathrm{Pb}$ using the ${ }^{207} \mathrm{~Pb}$-correction method. Decay constants from Steiger and Jäger (1977).

${ }^{3}$ 1-sigma errors.

${ }^{4}$ Radiogenic ratios, corrected for common $\mathrm{Pb}$ using the ${ }^{204} \mathrm{~Pb}$-correction method, based on the Stacey and Kramers (1975) model. 